\title{
Alkoxyamines Designed as Potential Drugs against Plasmodium and Schistosoma Parasites
}

\author{
Thibaud Reyser ${ }^{1,2}$, Tung H. To ${ }^{3}$, Chinedu Egwu ${ }^{1,2}$, Lucie Paloque ${ }^{1,2}$, Michel Nguyen ${ }^{1}$, \\ Alexandre Hamouy ${ }^{1}$, Jean-Luc Stigliani ${ }^{1}$, Christian Bijani ${ }^{1}$, Jean-Michel Augereau ${ }^{1,2}$, \\ Jean-Patrick Joly ${ }^{3}$, Julien Portela ${ }^{4}$, Jeffrey Havot ${ }^{3}$, Sylvain R. A. Marque ${ }^{3, *}$, Jérôme Boissier ${ }^{5, *}$, \\ Anne Robert 1,*(D), Françoise Benoit-Vical 1,2,6,*(D) and Gérard Audran ${ }^{3, *}$ \\ 1 Laboratoire de Chimie de Coordination du CNRS, LCC-CNRS, Université de Toulouse, CNRS, \\ 31555 Toulouse, France; thibaud.reyser@lcc-toulouse.fr (T.R.); chinedu.egwu@lcc-toulouse.fr (C.E.); \\ lucie.paloque@lcc-toulouse.fr (L.P.); michel.nguyen@lcc-toulouse.fr (M.N.); \\ alexandre.hamouy@gmail.com (A.H.); jean-luc.stigliani@lcc-toulouse.fr (J.-L.S.); bijani@lcc-toulouse.fr (C.B.); \\ jean-michel.augereau@lcc-toulouse.fr (J.-M.A.) \\ 2 Institut de Pharmacologie et de Biologie Structurale, IPBS, Université de Toulouse, CNRS, UPS, \\ 31077 Toulouse, France \\ 3 Aix Marseille University, CNRS, ICR, UMR 7273, Case 551, Avenue Escadrille Normandie-Niemen, \\ 13397 Marseille CEDEX 20, France; haitung.chem@gmail.com (T.H.T.); jp.joly@live.fr (J.-P.J.); \\ jeff94lb@gmail.com (J.H.) \\ 4 S.A.S ParaDev, 52 Avenue Paul Alduy, 66860 Perpignan, France; julien.portela@paradev.fr \\ 5 Laboratoire Interactions Hôtes-Pathogènes-Environnements (IHPE), UMR 5244 CNRS, \\ University of Perpignan, IFREMER, Univ. Montpellier, F-66860 Perpignan, France \\ 6 INSERM, Institut National de la Santé et de la Recherche Médicale, 31024 Toulouse, France \\ * Correspondence: sylvain.marque@univ-amu.fr (S.R.A.M.); boissier@univ-perp.fr (J.B.); \\ anne.robert@lcc-toulouse.fr (A.R.); Francoise.Vical@inserm.fr (F.B.-V.); g.audran@univ-amu.fr (G.A.)
}

Academic Editor: Elena G. Bagryanskaya

Received: 24 July 2020; Accepted: 10 August 2020; Published: 24 August 2020

\begin{abstract}
Malaria and schistosomiasis are major infectious causes of morbidity and mortality in the tropical and sub-tropical areas. Due to the widespread drug resistance of the parasites, the availability of new efficient and affordable drugs for these endemic pathologies is now a critical public health issue. In this study, we report the design, the synthesis and the preliminary biological evaluation of a series of alkoxyamine derivatives as potential drugs against Plasmodium and Schistosoma parasites. The compounds $(R S / S R)-\mathbf{2 F},(R R / S S)-\mathbf{2} \mathbf{F}$, and $\mathbf{8 F}$, having $\mathrm{IC}_{50}$ values in nanomolar range against drug-resistant $P$. falciparum strains, but also five other alkoxyamines, inducing the death of all adult worms of $S$. mansoni in only $1 \mathrm{~h}$, can be considered as interesting chemical starting points of the series for improvement of the activity, and further structure activity, relationship studies. Moreover, investigation of the mode of action and the rate constants $k_{\mathrm{d}}$ for $\mathrm{C}-\mathrm{ON}$ bond homolysis of new alkoxyamines is reported, showing a possible alkyl radical mediated biological activity. A theoretical chemistry study allowed us to design new structures of alkoxyamines in order to improve the selectivity index of these drugs.
\end{abstract}

Keywords: alkoxyamine; alkylation; heme; malaria; radical chemistry; schistosomiasis

\section{Introduction}

Malaria and schistosomiasis (=bilharziasis) are two human blood parasitic diseases that are widespread in tropical countries and often associated with coinfections. Current malaria treatments are based on artemisinin combination therapies (ACT) consisting of a semisynthetic derivative of the peroxide drug, artemisinin, in association with an antimalarial drug belonging to another 
therapeutic class. However, resistance of parasites to ACT is widespread in Southeast Asia [1,2], and artemisinin-resistant parasites display multi-resistant phenotypes [2-5]. In spite of this worrying situation, artemisinin and its derivatives are still the most efficient and rapidly acting antimalarial drugs, and the cornerstone of the therapy. Against schistosomiasis, praziquantel has been the mainstay of therapy for 40 years, but low sensitivity of parasites in many places have been reported for at least two decades [6]. We recently reported that the synthetic peroxide-based drugs, trioxaquines, are active against all the parasitic stages of both Plasmodium falciparum and Schistosoma mansoni, and have a synergistic effect when combined with praziquantel [6,7].

Human hemoglobin is digested by the blood parasites, Plasmodium and Schistosoma, to provide the amino acids required for the synthesis of parasite proteins. This metabolism results in the release of the hemoglobin cofactor, $\mathrm{Fe}(\mathrm{II})$-heme, which is toxic for the parasites, due to its capacity to induce the catalytic reduction in dioxygen leading to a fatal oxidative stress via Fenton chemistry. Both Plasmodium and Schistosoma share the same vital detoxification pathway, namely, the Fe(II)-heme polymerization, into an insoluble Fe(III) polymer, called hemozoin, which is unable to reduce dioxygen and, thus, is devoid of toxicity. The antimalarial activity of artemisinin involves the reductive activation of its peroxide function by $\mathrm{Fe}(\mathrm{II})$-heme, generating a C-centered radical that alkylates heme to form covalent heme-drug adducts, which are unable to polymerize and, consequently, retain a redox activity that is toxic for the parasites [8-10]. Fe(II)-heme is therefore acting as both the trigger and the target of the drug, through a controlled radical process. Such a mechanism of action has been reported for the other peroxide-based drugs [11], trioxaquines [12-15]. Alkylation of heme by trioxaquines has been evidenced in vivo, both in malaria parasite [14] and in Schistosoma [16].

With the aim to develop a series of drugs expected to be active against both malaria and schistosomiasis, we prepared stable alkoxyamine derivatives. Homolysis of the NO-C bond of alkoxyamines, which is the reverse reaction of the well-known trapping of alkyl radical by stable nitroxides, is supposed to occur in vivo, and generate alkyl radicals that are expected to alkylate heme, prevent its polymerization, and cause oxidative lethal damage to the parasites, in a similar fashion to artemisinin and synthetic peroxides (Figure 1). However, due to the absence of the peroxide function, alkoxyamines may maintain their activity against artemisinin-resistant parasites. On this exploratory topic, we report here the synthesis and the in vitro activities of a series of alkoxyamines against $P$. falciparum and S. mansoni. As a preliminary investigation of the mechanism of action of these drugs, their reactivity toward heme is reported, as well as a new hypothesis on their antimalarial mechanism of action.

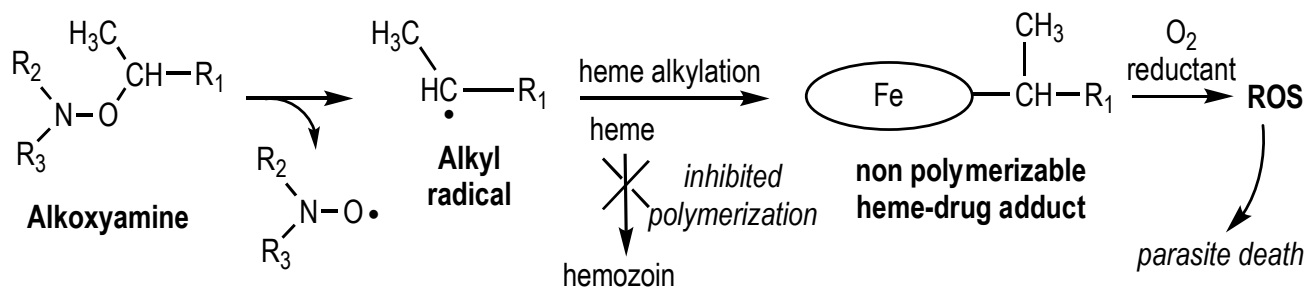

Figure 1. Expected alkylation of heme after homolysis of alkoxyamines, leading to a lethal oxidative stress within blood parasites (the oval stands for the porphyrin macrocycle).

\section{Results and Discussion}

\subsection{Synthesis of Alkoxyamines}

Among more than a hundred of prepared alkoxyamines (see Figure S1), the derivatives whose synthesis, reactivity and biological activity will be discussed in detail are depicted in Figure 2. Most of the alkoxyamines were prepared as previously reported [17-27]. The syntheses of new compounds are depicted in Scheme 1 (compound 6F), Scheme 2 (compound 2F and 4F), and Scheme 3 (compound 8F). First, as reported [28], the 4-piperidone 15 was treated with triflic anhydride to yield triflate $\mathbf{1 6}$ (94\% 
yield) (Scheme 1). A Stille coupling of vinyltributyltin with triflate $\mathbf{1 6}$ produced the arylvinyl derivative 17 ( $82 \%$ yield). Attempts to synthetize the alkoxyamines, $6 \mathrm{~F}$ from arylvinyl 17 using metal complexes based on manganese [29], failed, leading us to investigate a new pathway. Thus, hydrogenolysis of arylvinyl 17, followed by allylic bromination using NBS in $\mathrm{CCl}_{4}$, provided the bromide derivative 18 . Furthermore, the coupling of the alkyl radical, generated in situ by the action of copper catalysts to the bromide derivative with the nitroxide SG1-OTBS [23], was successful, producing the alkoxyamines $\mathbf{6 F}$ as a 2:1 mixture of diastereomers (75\% yield).

At this stage, the two stereoisomers were easily separated by column chromatography to produce $1.10 \mathrm{~g}$ of $(R S / S R)-6 \mathrm{~F}$ and $510 \mathrm{mg}$ of (RR/SS)-6F, respectively. Recrystallization of (RR/SS)-6F [30] in diethyl ether yielded white single crystals which were $\mathrm{X}$-ray analyzed (Figure $3 a$ ).

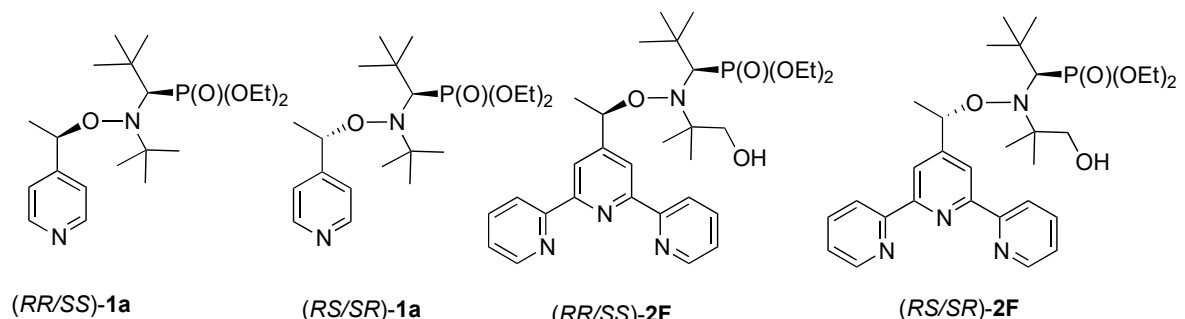<smiles>CCOC(=O)[C@H]([C@@H](OCC)C(C)(C)C)N(C)C(C)(C)C</smiles>

Figure 2. Structures of alkoxyamines 1a, 2F, 4F, 2G and 8F.

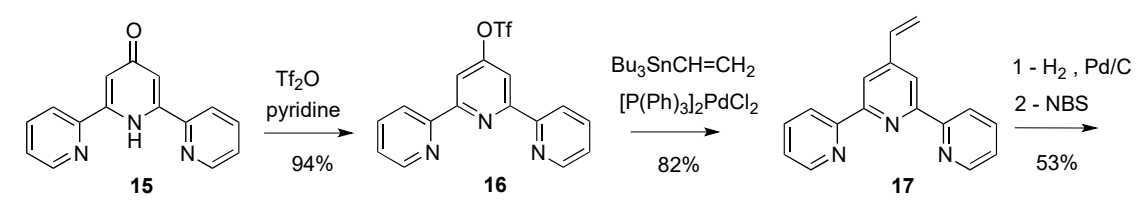

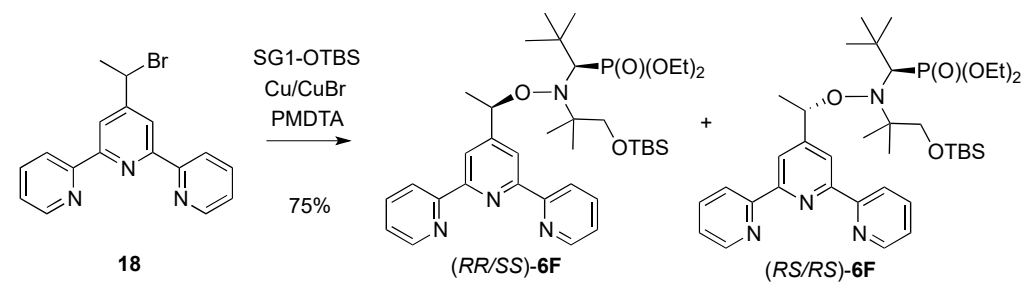

Scheme 1. Synthesis of alkoxyamines (RR/SS)-6F and (RS/SR)-6F.

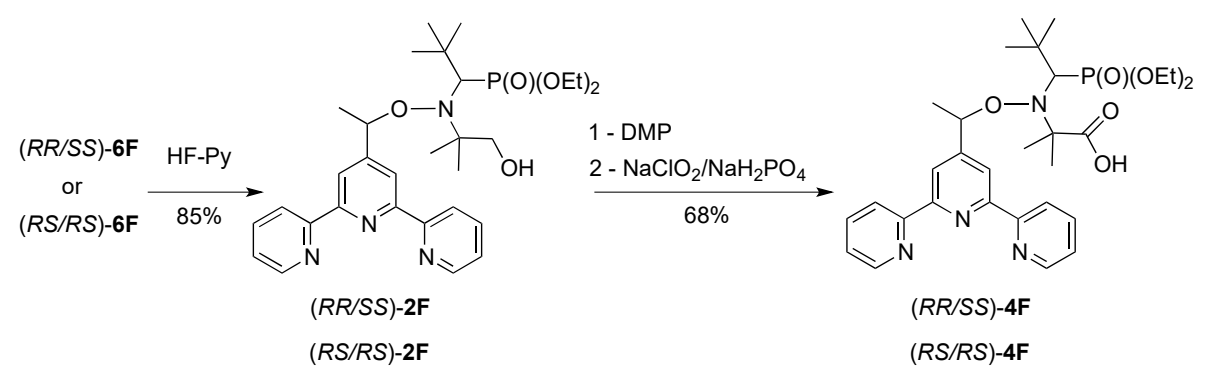

Scheme 2. Synthesis of alkoxyamines (RR/SS)-2F, (RS/SR)-2F, (RR/SS)-4F and (RS/SR)-4F. 
<smiles>CC(Br)c1cc(-c2ccccn2)nc(-c2ccccn2)c1</smiles>

18

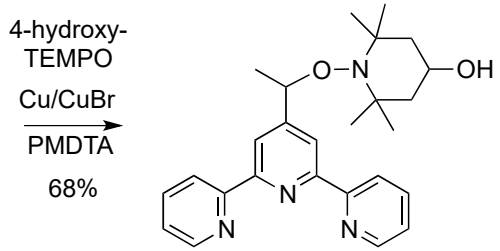

$(R / S)-8 \mathbf{F}$

Scheme 3. Synthesis of alkoxyamines (R/S)-8F.

The following steps were performed on each diastereomer (Scheme 2). Firstly, HF/pyridine [31] deprotection of $(R S / S R)-6 \mathbf{F}$ yielded the primary alcohol derivative $(R S / S R)-2 \mathrm{~F}$. Finally, the oxidation of the alcohol into aldehyde under mild conditions using Dess-Martin periodinane (DMP) [32], followed by a Pinnick oxidation procedure [33], provided the carboxylic acid (RS/SR)-4F. Using (RR/SS)-6F, the alcohol $(R R / S S)-2 \mathbf{F}$, aldehyde and carboxylic acid $(R R / S S)-4 \mathbf{F}$ were also prepared using the same methodology as described for $(R S / S R)-6 \mathbf{F}$.

The synthesis of the alkoxyamine $(R / S)-8 \mathbf{F}$ ( $68 \%$ yield) was accomplished by coupling the alkyl radical, generated in situ by the action of copper catalysts to the bromide 18, with 4-hydroxy-TEMPO.

The alkoxyamine $\mathbf{2 G}$ was prepared from commercially available $5^{\prime}$-bromo-m-terphenyl 19 (Scheme 4) as follows. Firstly, a Stille coupling using vinyl tributyltin afforded the $5^{\prime}$-vinyl-m-terphenyl 20 in $80 \%$ yield. The alkoxyamines (RR/SS)-6G and (RS/SR)-6G were obtained in $70 \%$ yield by the use of metal complexes based on manganese [29], and easily separated by column chromatography. The deprotection of (RS/SR)-6G and (RR/SS)-6G using HF/pyridine [32] yielded the alcohols, $(R S / S R)-2 \mathrm{G}$ and $(R R / S S)-2 \mathrm{G}$, respectively, in $85 \%$ yield. After purification, recrystallization of $(R R / S S)-2 \mathrm{G}$ [30] in diethyl ether yielded white single crystals which were X-ray analyzed (Figure $3 b$ ).

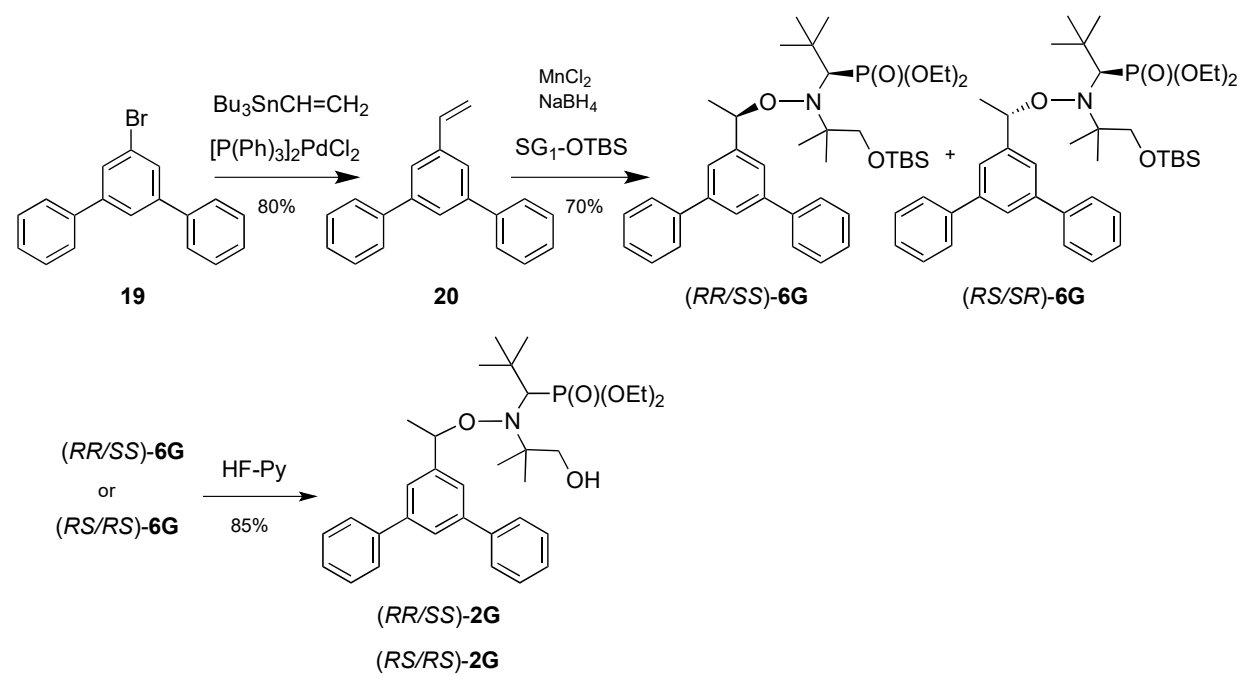

Scheme 4. Synthesis of alkoxyamines (RR/SS)-2G and (RS/SR)-2G.

(a)

$(R R / S S)-6 \mathbf{F}$

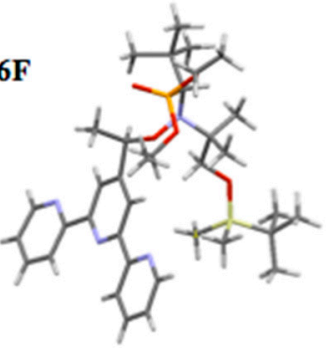

(b) $(R R / S S)-\mathbf{2 G}$

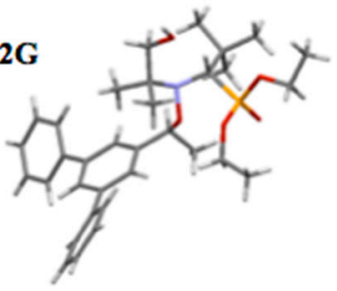

Figure 3. Ortep drawing from X-ray analysis of (a) $(R R / S S)-6 \mathbf{F}$ (Figure 3a) and (b) $(R R / S S)-2 \mathrm{G}$. 


\subsection{Antimalarial Activity}

We first screened 105 alkoxyamines and moieties on the reference $P$. falciparum strain FcB1-Columbia, twice at $10 \mu \mathrm{M}$. Most of the drugs did not induce antiplasmodial activities at $10 \mu \mathrm{M}$ except 22 molecules which demonstrated a significant parasite growth inhibition at this concentration. These selected molecules were therefore subsequently tested twice in a standard chemosensitivity assay to determine their $\mathrm{IC}_{50}$ values. Out of these 22 molecules, 15 exhibited $\mathrm{IC}_{50}$ values largely lower than $10 \mu \mathrm{M}$ with $(R S / S R)-\mathbf{2 F},(R R / S S)-\mathbf{2 F}$, and $(R / S)-\mathbf{8 F}$ as the most active ones with $\mathrm{IC}_{50}$ values in the 140-300 nM range (see Supporting Information, Table S1). Due to the large artemisinin resistance challenge in the field, we further evaluated the activity of the 18 drugs exhibiting the lowest $\mathrm{IC}_{50}$ values, on both artemisinin-resistant parasites, F32-ART5 and artemisinin-sensitive parasites, F32-TEM. The activities were close to that previously found on the chloroquine-resistant strain FcB1-Columbia. Therefore, we confirmed high antiplasmodial activities of seven molecules, especially (RS/SR)-2F, $(R R / S S)-\mathbf{2 F}$, and $(R / S)-\mathbf{8 F}$ which were considered as the chemical starting points of the series (Table 1).

Table 1. Antiplasmodial and antischistosomal activities detailed for the best alkoxyamines and cytotoxicity on Vero cell lines.

\begin{tabular}{|c|c|c|c|c|c|}
\hline & \multirow{2}{*}{$\begin{array}{c}\text { S. mansoni } \\
\text { Mean Survival Time (h) } \\
\text { Adult S. mansoni }\end{array}$} & \multicolumn{2}{|c|}{$\begin{array}{l}\text { P. falciparum Strains } \\
\text { Mean } \mathrm{IC}_{50}(\mu \mathrm{M})\end{array}$} & \multirow{2}{*}{$\begin{array}{c}\text { Cytotoxicity } \\
\text { Mean } \mathrm{IC}_{50}(\boldsymbol{\mu M})\end{array}$} & \multirow[t]{2}{*}{$\begin{array}{l}\text { Selectivity } \\
\text { Index }\end{array}$} \\
\hline & & F32-TEM & F32-ART5 & & \\
\hline$(R R / S S)-\mathbf{1 a}$ & $>8$ & $15^{2}$ & $16^{2}$ & $17 \pm 7.0$ & 1 \\
\hline$(R S / S R)-\mathbf{1 a}$ & $1.2 \pm 0.1$ & $7.6^{2}$ & $11^{2}$ & $28 \pm 29$ & 3 \\
\hline$(R S / S R)-\mathbf{2 F}$ & $2.1 \pm 0.1$ & $0.6 \pm 0.1$ & $0.5 \pm 0.1$ & $0.8 \pm 0.3$ & 1 \\
\hline$(R R / S S)-\mathbf{2 F}$ & $2.5 \pm 0.2$ & $0.5 \pm 0.1$ & $0.4 \pm 0.1$ & $0.7 \pm 0.3$ & 1 \\
\hline$(R S / S R)-4 \mathbf{F}$ & $5.2 \pm 0.2$ & $2.9^{2}$ & $4.7^{2}$ & $15 \pm 5.0$ & 4 \\
\hline$(R R / S S)-\mathbf{4 F}$ & $>8$ & $4.6^{1}$ & $4.6^{1}$ & $8.1 \pm 3.3$ & 2 \\
\hline$(R / S)-8 \mathbf{F}$ & $5.0 \pm 0.0$ & $1.3^{2}$ & $1.1^{2}$ & $0.7 \pm 0.4$ & 0.5 \\
\hline$(R S / S R)-7 \mathbf{F}$ & $2.7 \pm 0.1$ & $1.3^{2}$ & $1.4^{2}$ & $0.9 \pm 0.4$ & 0.6 \\
\hline$(R R / S S)-7 \mathbf{F}$ & $2.5 \pm 0.1$ & $0.94^{2}$ & $0.85^{2}$ & $1.2 \pm 1.3$ & 1 \\
\hline 1J & $1.1 \pm 0.1$ & $2.9^{1}$ & $2.3^{1}$ & $6.2 \pm 1.2$ & 2 \\
\hline $1 \mathrm{~K}$ & $1.1 \pm 0.0$ & $1.1^{1}$ & $1.6^{1}$ & $1.1 \pm 0.7$ & 1 \\
\hline $2 \mathrm{~J}$ & $1.0 \pm 0.0$ & $5.0^{1}$ & $4.6^{1}$ & $17 \pm 6.3$ & 3 \\
\hline$(R S / S R)-\mathbf{1 L}$ & $\mathrm{ND}^{3}$ & $11^{2}$ & $18^{2}$ & ND & ND \\
\hline$(R R / S S)-\mathbf{1 L}$ & ND & $20^{2}$ & $26^{2}$ & 28 & 1 \\
\hline$(R S / S R)-\mathbf{1 M}$ & ND & $5.8^{2}$ & $4.9^{2}$ & $13 \pm 1.5$ & 2 \\
\hline$(R R / S S)-\mathbf{1} \mathbf{M}$ & ND & $4.8^{2}$ & $6^{2}$ & $6.5 \pm 0.3$ & 1 \\
\hline 22 & $>8$ & $0.24^{1}$ & $0.23^{1}$ & $5.3 \pm 4.5$ & 22 \\
\hline $9 a$ & $3.0 \pm 0.0$ & $7.5^{1}$ & $13^{1}$ & $40 \pm 13$ & 3 \\
\hline$(R S / S R)-\mathbf{1 A}$ & $1.0 \pm 0.05$ & ND & ND & 21 & \\
\hline$(R R / S S)-\mathbf{1 A}$ & $1.0 \pm 0.05$ & ND & ND & $>100$ & \\
\hline$(R R / S S)-\mathbf{1} \mathbf{p}$ & $1.0 \pm 0.05$ & ND & ND & $>100$ & \\
\hline$(R R / S S)-\mathbf{1 k}$ & $1.0 \pm 0.05$ & ND & ND & & \\
\hline Praziquantel & $1.0 \pm 0.05$ & ND & ND & $>>100^{5}$ & $>>100$ \\
\hline Artemisinin & ND & $0.02 \pm 0.001^{6}$ & $0.02 \pm 0.002^{6}$ & $160 \pm 12$ & 8000 \\
\hline Chloroquine & ND & $0.06 \pm 0.02$ & $0.06 \pm 0.03$ & $190 \pm 56$ & 3000 \\
\hline
\end{tabular}

${ }^{1} n=1 ;{ }^{2} n=2 ;{ }^{3} \mathrm{ND}=$ not determined; ${ }^{4}$ selectivity indexes are calculated as the ratio-cytotoxicity/activity on Plasmodium. As the activity on Schistosoma was based on a single dose treatment at $100 \mu \mathrm{g} / \mathrm{mL}$, results are reported by a mean survival time, hence the selectivity index on Schistosoma cannot be calculated; ${ }^{5}$ data from Reference [34]; ${ }^{6}$ F32-ART5 is artemisinin-resistant and F32-TEM is artemisinin-sensitive. However, as artemisinin resistance is a quiescence-based phenomenon [35], these strains cannot be segregated by standard assays based on parasite proliferation. F32-ART and F32-TEM are chloroquine-sensitive.

Nevertheless, artemisinin resistance is a quiescence-based phenomenon and thus not identifiable by standard assays based on parasite proliferation [35]. In fact, as reported in Table 1, no $\mathrm{IC}_{50}$ difference was observed for artemisinin between artemisinin-sensitive and artemisinin-resistant strains. That is why, in order to evaluate whether or not alkoxyamine may exhibit cross resistance with artemisinin, 
we further tested the compound $(R S / S R)-2 F$ in a recrudescence assay designed to evaluate a putative cross-resistance between artemisinin and (RS/SR)-2F on artemisinin-resistant F32-ART5 parasites (Table 2).

We found a significant delay in parasite recrudescence between both strains after the (RS/SR)-2F treatment since the F32-ART5 (artemisinin-resistant) parasites reached the $t_{0}$ initial parasitemia approximately 14 days before the F32-TEM (artemisinin-sensitive) parasites in a similar manner to artemisinin, thus demonstrating a cross-resistance between artemisinin and (RS/SR)-2F. This result evidenced that alkoxyamine $(R S / S R)-\mathbf{2 F}$ is less active against artemisinin-resistant parasites than the artemisinin-sensitive ones (Table 2). To explain this experimental in vitro cross-resistance, we hypothesize that the $(R S / S R)-2 \mathrm{~F}$ mediated stress induction is likely able to activate the metabolic pathways involved in the quiescence entrance of the artemisinin-resistant parasites.

Table 2. Recrudescence assay on artemisinin-resistant (F32-ART5) and artemisinin-sensitive (F32-TEM) strains.

\begin{tabular}{ccccc}
\hline \multirow{2}{*}{ Drug (Dose) } & \multicolumn{2}{c}{ Median (Range) Recrudescence Time } \\
& \multicolumn{2}{c}{ (Days) } & $\begin{array}{c}\text { Mean } \pm \text { SEM Difference of } \\
\text { Recrudescence Time (Days) }\end{array}$ & $p$-value \\
\cline { 2 - 3 } & F32-ART5 & F32-TEM & $>16.3 \pm 3.7$ & 0.048 \\
\hline Artemisinin $(18 \mu \mathrm{M})$ & $9(7-11)$ & $>30(16 \rightarrow 30)^{1}$ & $>14 \pm 0.6$ & 0.0017 \\
$(R S / S R)-2 F(5 \mu \mathrm{M})$ & $16(15-17)$ & $>30^{1}$ & \\
\hline
\end{tabular}

${ }^{1}$ If no parasites were observed at the end of the experiment (i.e., after 30 days), the culture was classified as showing no recrudescence and the recrudescence day was noted as $>30$ days. For statistical purposes, the values corresponding to the cultures showing no recrudescence were censored and their values aligned to the last day of monitoring.

\subsection{Antischistosomal Activity}

Table 1 summarizes the molecules with the best antischistosomal activities referenced in the Supplementary Table S1. In vitro activity against adult S. mansoni was assessed with a set of 74 alkoxyamine derivatives, at $100 \mu \mathrm{g} / \mathrm{mL}$, corresponding to 150-320 $\mu \mathrm{M}$. Out of these drugs, 37 induced the death of all the parasites in 1 to $8 \mathrm{~h}$ after the drug addition to the parasite culture media (Table S1). Five molecules, $(R R / S S)-\mathbf{1 k},(R R / S S)-\mathbf{1 p},(R S / S R)-\mathbf{1 A},(R R / S S)-\mathbf{1 A}$ and 2J, exhibited the highest antischistosomal activities by killing all the parasites after $1 \mathrm{~h}$ of incubation. Furthermore, nine molecules exhibited antischistosomal effects between 1 and $2 \mathrm{~h}$, while nine killed all worms between 2 to $3 \mathrm{~h}$. Finally, eight and five molecules showed antischistosomal activities between 3-4 h and $4-6 \mathrm{~h}$, respectively.

Notably, $(R / S)-8 F,(R S / S R)-2 F$ and $(R R / S S)-2 F$ exhibited the highest activity against $P$. falciparum. However, these drugs were not the most active against $S$. mansoni. Indeed, they induced the death of all adult worms in only 5, 2.1 and $2.5 \mathrm{~h}$, respectively. Conversely, $(R R / S S)-\mathbf{1 k},(R R / S S)-\mathbf{1 p},(R S / S R)-\mathbf{1 A}$, and $(R R / S S)-\mathbf{1 A}$, displaying the highest activities towards Schistosoma, were devoid of significant activity against the FcB1-Columbia Plasmodium strain $\left(\mathrm{IC}_{50}>10 \mu \mathrm{M}\right.$, Table S1). In the reported alkoxyamine series, compound $2 \mathrm{~F}$ was found to be the best compromise for antimalarial and antischistosomal activities, with antiplasmodial $\mathrm{IC}_{50}$ values below $1 \mu \mathrm{M}(0.2-0.3 \mu \mathrm{M}$ on the FcB1 strain, Table S1, and $0.4-0.6 \mu \mathrm{M}$ on the F32 strains, Table 1), and a mean survival time of adult S. mansoni in the 2.1-2.5 $\mathrm{h}$ range.

\subsection{Cytotoxicity}

For 20 molecules showing the highest antiparasitic activity, their cytotoxicity was evaluated against the non-cancerous mammalian Vero cell line, in order to determine their selectivity indexes (Table 1). Unfortunately, the whole series of molecules with promising antiplasmodial activity presented weak selectivity indexes with poor cytotoxic/antiparasitic ratios, suggesting that the observed activity against $P$. falciparum is not due to a specific antiparasitic process. 


\subsection{Thermodynamic and Kinetic Data for the Homolysis of the NO-C Bond}

Homolysis rate constants $k_{\mathrm{d}}$ ' were measured by EPR and estimated using Equation (1) as reported many times in the literature. Further, $E_{\mathrm{a}}$ and $k_{\mathrm{d}}$ were estimated using Equation (2). Results are reported in Table 3.

$$
\begin{gathered}
\ln \left(\frac{[\text { nitroxide }]_{\infty}-[\text { nitroxide }]_{t}}{[\text { nitroxide }]_{\infty}}\right)=-k_{\mathrm{d}} \cdot t \\
E_{\mathrm{a}}=-\mathrm{RT} \ln \left(\frac{E_{\mathrm{a}}}{k_{\mathrm{d}}} \text { or } k_{\mathrm{d}}^{\prime}\right)
\end{gathered}
$$

The difference in $E_{\mathrm{a}}$ for diastereoisomers is less than $4 \mathrm{~kJ} / \mathrm{mol}$ as already reported for molecules in the same family. $\mathrm{pH}$ was determined by standard procedure [36]. This difference is due to small differences in steric strain between diastereoisomers, as previously observed, and does not deserve more comment. As expected for meta-substituted regioisomer, $E_{\mathrm{a}}$ of $6 \mathrm{G}$ is very close to the models $\mathbf{1 z}$ and $\mathbf{6 z}$. Due to the intramolecular hydrogen bonding (IHB) in $\mathbf{2 G}, E_{\mathrm{a}}$ of $\mathbf{2 G}$ is ca. $4 \mathrm{~kJ} / \mathrm{mol}$ lower than for $6 \mathrm{G}$ as expected from the models $2 \mathrm{Z}$ and $6 \mathrm{Z}$. As expected from the IHB-suppressing effect of the $\mathrm{MeOH} /$ water solvent mixture, $E_{\mathrm{a}}$ of $\mathbf{2 G}$ is slightly larger than the one of $\mathbf{2 G}$ (given in $t$ - $\mathrm{BuPh}$ ). As observed for $1 \mathrm{a}$ and $\mathbf{1 z}, E_{\mathrm{a}}$ of $\mathbf{1 6}$ is slightly lower than the one of $\mathbf{6 G}$ due to the slightly more polar alkyl fragment in $6 \mathrm{~F}$ than in $6 \mathrm{G}$. As observed for $6 \mathrm{G}$ and $\mathbf{2 G}, E_{\mathrm{a}}$ of $\mathbf{2 F}$ is lower by $2-3 \mathrm{~kJ} / \mathrm{mol}$ according to $6 \mathbf{F}$. In contrast to $1 \mathrm{a}$, protonation of $2 \mathrm{~F}$ produces a small decrease of $2 \mathrm{~kJ} / \mathrm{mol}$ in $E_{\mathrm{a}}$. This unexpected weak effect is ascribed to the distribution of the positive charge on the two heteroaromatic rings in position meta, leading to a weaker charge on the ipso carbon atom in the alkyl fragment of $2 \mathbf{F H}^{+}$. On the other hand, in water under strong acidic conditions, the expected decrease in $E_{\mathrm{a}}$ by $7-8 \mathrm{~kJ} / \mathrm{mol}$ is observed from $\mathbf{2 F}$ to $\mathbf{2} \mathbf{F H}^{+}$. Upon in situ coordination of $\mathbf{2 F}$ with $\mathrm{FeCl}_{2}$, a decrease by $1 \mathrm{~kJ} / \mathrm{mol} \mathrm{was}$ observed as expected from the coordination of $1 \mathrm{a}$ with $\mathrm{Zn}(\mathrm{hfac})^{2}$, meaning that the partial positive charge is mainly located on the central aryl moiety of $2 \mathrm{FFe}^{2+}$.

Surprisingly, coordination of $2 \mathrm{~F}$ by $\mathrm{FeCl}_{3}$ produces only a decrease by $2-3 \mathrm{~kJ} / \mathrm{mol}$ in $2 \mathrm{FFe}^{3+}$ in contrast to $2 \mathrm{FFe}^{2+}$. At this time, no rationale is available.

The differences observed between $\mathbf{9 F}$ and $\mathbf{9} \mathbf{F H}^{+}$are similar to those reported for models $\mathbf{9 a}$ and $\mathbf{9 z}$, and the comments for $\mathbf{1}$ derivatives hold (for the structure of $\mathbf{9 F}$, see Supporting Information, Figure S1).

Noteworthy, for the alkoxyamine $2 \mathrm{~F}$ containing a terpyridine moiety, protonation of the terpyridine residue resulted in a drastic activation of the homolysis: in an aqueous medium, $\mathrm{t}_{1 / 2}$ were 2.7 and 3.5 days at $\mathrm{pH} 7.4$ for $(R S / S R)-2 \mathrm{~F}$ and $(R R / S S)-2 \mathrm{~F}$, respectively, compared to $5.6 \mathrm{~h}$ and $1 \mathrm{~h}$ at $\mathrm{pH} 1 \mathrm{for}$ $(R S / S R)-\mathbf{2} \mathbf{F H}^{+}$and $(R R / S S)-\mathbf{2} \mathbf{F H}^{+}$, respectively. Due to the low $\mathrm{pKa}$ of terpyridine, this activation is not expected to be biologically relevant. However, complexation of the terpyridine by a Lewis acid such as $\mathrm{Fe}^{2+}$, also provided a significant decrease in the alkoxyamine $\mathrm{t}_{1 / 2}$ value $(2 \mathrm{~h}$ and $1.8 \mathrm{~h}$ at $\mathrm{pH} 7.4$ for $(R S / S R)-2 F^{2+} e^{2+}$ and $(R R / S S)-2 F^{2+} e^{2+}$, respectively). The homolysis can therefore be activated in the complex in vivo medium, by actually unidentified mechanisms.

Table 3. Experimental homolysis rate constant $k_{\mathrm{d}}{ }^{\prime}$ for alkoxyamines 16, 2F, 8F, 9F, 2G and 6G using the EPR technique and Equation (2), in various conditions, corresponding activation energies $E_{\mathrm{a}}$,

\begin{tabular}{|c|c|c|c|c|c|c|c|c|c|c|}
\hline & \multirow{2}{*}{ Solvent } & \multirow{2}{*}{$T\left({ }^{\circ} \mathrm{C}\right)^{a}$} & \multicolumn{2}{|c|}{$k_{\mathrm{d}}^{\prime}\left(10^{-4} \mathrm{~s}^{-1}\right)^{b}$} & \multicolumn{2}{|c|}{$E_{\mathrm{a}}(\mathrm{kJ} / \mathrm{mol})^{c, d}$} & \multicolumn{2}{|c|}{$k_{\mathrm{d}}\left(10^{-3} \mathrm{~s}^{-1}\right)^{d}$} & \multicolumn{2}{|c|}{$t_{1 / 2}$ (day) $^{e}$} \\
\hline & & & $R S / S R^{f}$ & $R R / S S^{f}$ & $R S / S R^{f}$ & $R R / S S^{f}$ & $R S / S R^{f}$ & $R R / S S^{f}$ & $R S / S R^{f}$ & $R R / S S^{f}$ \\
\hline $6 \mathrm{~F}$ & $t$-BuPh & 81 & 2.7 & 1.4 & 121.7 & 123.8 & 16.3 & 8.5 & 10 & 24 \\
\hline $2 \mathrm{~F}$ & $t$-BuPh & 81 & 5.3 & 7.0 & 119.7 & 118.9 & 29.9 & 38.4 & 4.8 & 3.5 \\
\hline $2 \mathrm{FH}^{+}$ & $\begin{array}{c}t-\mathrm{BuPh}+2 \mathrm{eq} \\
\mathrm{TFA}^{g}\end{array}$ & 80 & 8.7 & 6.7 & 117.9 & 118.2 & 51.8 & 40.9 & 2.4 & 3.3 \\
\hline $2 \mathrm{~F}$ & $\begin{array}{l}\mathrm{MeOH} / \text { water } \\
1: 1 p \mathrm{H}=7.4^{h}\end{array}$ & 81 & 8.7 & 7.1 & 118.2 & 118.8 & 46.7 & 38.9 & 2.7 & 3.5 \\
\hline
\end{tabular}
re-estimated homolysis rate constant $k_{\mathrm{d}}$ at $120^{\circ} \mathrm{C}$, and half-lifetime $\mathrm{t}_{1 / 2}$ at $37^{\circ} \mathrm{C}$. 
Table 3. Cont

\begin{tabular}{|c|c|c|c|c|c|c|c|c|c|c|}
\hline & \multirow{2}{*}{ Solvent } & \multirow{2}{*}{$T\left({ }^{\circ} \mathrm{C}\right)^{a}$} & \multicolumn{2}{|c|}{$k_{\mathrm{d}^{\prime}}\left(10^{-4} \mathrm{~s}^{-1}\right)^{b}$} & \multicolumn{2}{|c|}{$E_{\mathrm{a}}(\mathrm{kJ} / \mathrm{mol})^{c, d}$} & \multicolumn{2}{|c|}{$k_{\mathrm{d}}\left(10^{-3} \mathrm{~s}^{-1}\right)^{d}$} & \multicolumn{2}{|c|}{$t_{1 / 2}$ (day) $^{e}$} \\
\hline & & & $R S / S R^{f}$ & $R R / S S^{f}$ & $R S / S R^{f}$ & $R R / S S^{f}$ & $R S / S R^{f}$ & $R R / S S^{f}$ & $R S / S R^{f}$ & $R R / S S^{f}$ \\
\hline $2 \mathrm{FH}^{+}$ & $\begin{array}{l}\mathrm{MeOH} / \text { water } \\
1: 1 p \mathrm{H}=1.0^{h} \\
\mathrm{MeOH} / \text { water }\end{array}$ & 51 & 2.1 & 12.0 & 111.9 & 107.4 & 310.1 & 1305 & $5.6 \mathrm{~h}$ & $1.0 \mathrm{~h}$ \\
\hline $2 \mathrm{FFe}^{2+}$ & $\begin{array}{c}1: 1 p \mathrm{H}=7.4^{h} \\
\mathrm{FeCl}_{2} \\
\mathrm{MeOH} / \text { water }\end{array}$ & 60 & 17.8 & $-i$ & 109.2 & j & 732.0 & -j & $2 \mathrm{~h}$ & $j$ \\
\hline $2 \mathrm{FFe}^{2+}$ & $\begin{array}{c}1: 1 p \mathrm{H}=7.4^{h} \\
\mathrm{FeCl}_{2} \\
\mathrm{MeOH} / \text { water }\end{array}$ & 51 & $-i$ & 6.5 & - j & 109.0 & $-j$ & 787.0 & -j & $1.8 \mathrm{~h}$ \\
\hline $2 \mathrm{FFe}^{3+}$ & $\begin{array}{c}1: 1 p \mathrm{H}=7.4^{h} \\
\mathrm{FeCl}_{3}\end{array}$ & 51 & 3.9 & ${ }_{-} i$ & 116.4 & $-j$ & 83.4 & $-j$ & 1.3 & $-j$ \\
\hline $2 \mathrm{FFe}^{3+}$ & $\begin{array}{c}\mathrm{MeOH} / \text { water } \\
1: 1 p \mathrm{H}=7.4^{h} \\
\mathrm{FeCl}_{3}\end{array}$ & 61 & $-i$ & 2.0 & $-j$ & 115.1 & $-j$ & 120.6 & $-j$ & 8.1 \\
\hline $9 \mathrm{~F}$ & $t$-BuPh & 111 & \multicolumn{2}{|c|}{$3.7^{k}$} & \multicolumn{2}{|c|}{$131.0^{k}$} & \multicolumn{2}{|c|}{$0.95^{k}$} & \multicolumn{2}{|c|}{$385^{k}$} \\
\hline $9 \mathrm{FH}^{+}$ & $\begin{array}{c}t-\mathrm{BuPh}+2 \text { eq. } \\
\mathrm{TFA}^{g}\end{array}$ & 101 & \multicolumn{2}{|c|}{$3.0^{k}$} & \multicolumn{2}{|c|}{$128.2^{k}$} & \multicolumn{2}{|c|}{$2.2^{k}$} & \multicolumn{2}{|c|}{$385^{k}$} \\
\hline $9 \mathrm{~F}$ & $\begin{array}{l}\mathrm{MeOH} / \text { water } \\
1: 1 p \mathrm{H}=7.4^{h}\end{array}$ & 90 & \multicolumn{2}{|c|}{$0.25^{k}$} & \multicolumn{2}{|c|}{$131.9^{k}$} & \multicolumn{2}{|c|}{$0.7^{k}$} & \multicolumn{2}{|c|}{$385^{k}$} \\
\hline $8 \mathrm{~F}$ & $t-\mathrm{BuPh}$ & 111 & \multicolumn{2}{|c|}{1.9} & \multicolumn{2}{|c|}{$133.3^{k}$} & \multicolumn{2}{|c|}{0.46} & \multicolumn{2}{|c|}{$941^{k}$} \\
\hline $6 \mathrm{G}$ & $t-\mathrm{BuPh}$ & 92 & 3.5 & 2.7 & 124.7 & 125.5 & 6.50 & 5.10 & 45.3 & 33.4 \\
\hline $2 \mathrm{G}$ & $t$-BuPh & 81 & 3.7 & 3.8 & 120.8 & 120.8 & 21.6 & 21.1 & 7.5 & 7.5 \\
\hline $2 \mathrm{G}$ & $\begin{array}{l}\mathrm{MeOH} / \text { water } \\
2: 1 p \mathrm{H}=7.0^{h}\end{array}$ & 81 & 2.3 & 3.3 & 122.1 & 121.1 & 14.4 & 19.5 & 12.7 & 12.3 \\
\hline
\end{tabular}

${ }^{a}$ Error $\pm 1{ }^{\circ} \mathrm{C} .{ }^{b}$ Statistical error less than $5 \% .{ }^{c}$ Currently accepted error $\pm 1 \mathrm{~kJ} / \mathrm{mol} .{ }^{d}$ Estimated using Equation (1) and assuming an averaged frequency factor $\mathrm{A}=2.4 \times 10^{14} \mathrm{~s}^{-1} .{ }^{e}$ Unless otherwise mentioned. ${ }^{f}$ Diastereoisomers were separated unless otherwise mentioned. ${ }^{g}$ TFA: trifluoroacetic acid. Protonation was checked by ${ }^{1} \mathrm{H}-\mathrm{NMR}$. ${ }^{h} \mathrm{pH}$ was corrected as reported in [37]. ${ }^{i}$ Not measured. ${ }^{j}$ Not estimated. ${ }^{k}$ No diastereoisomers. ${ }^{l}$ Mixture of diastereoisomers afforded only monoexponential growth of nitroxide meaning that the two diastereoisomers exhibit the same values of $k_{\mathrm{d}}$.

\subsection{Reactivity of Alkoxyamines Toward Heme}

Since alkoxyamines were designed to generate radicals with putative alkylating ability toward heme, the homolysis of the drugs, and the fate of the generated alkyl radicals were investigated in the presence of heme, with the aim to correlate heme alkylation with antiplasmodial activity. We first compared the reactivity with heme of two couples of diastereomer racemates: alkoxyamines $(R R / S S)-\mathbf{1 a}$ and $(R S / S R)-1$ a on the one hand, which exhibit a very low activity in vitro $\left(\mathrm{IC}_{50}>3 \mu \mathrm{M}\right.$ on FcB1-columbia P. falciparum), and (RS/SR)-2F and (RR/SS)-2F on the other hand, which exhibit a significantly higher activity ( $\mathrm{IC}_{50}=0.3$ and $0.2 \mu \mathrm{M}$, respectively) (see Figure 2 for the structures). The reactivity of $\mathbf{8 F}$ was then compared to that of $2 \mathrm{~F}$ made of the same alkyl fragment, but with a different nitroxide moiety. $\mathrm{T}_{1 / 2}$ values of alkoxyamines $(R R / S S)-\mathbf{1 a} /(R S / S R)-\mathbf{1 a}[\mathbf{1 7}, \mathbf{1 8}]$ and $(R R / S S)-\mathbf{2} \mathbf{F} /(R S / S R)-\mathbf{2 F}$ (Table 3$)$ in vitro at $37^{\circ} \mathrm{C}$ are in the $2-4$ day range in aqueous medium and 17 days and $3-5$ days, respectively, in tert-butylbenzene, while the $\mathrm{t}_{\mathbf{1} / 2}$ of $\mathbf{8 F}$ in tert-butylbenzene is as long as 2.5 years (Table 3 ). Homolysis of the NO-C bond in vivo may be activated by several factors, namely, protonation or coordination of pyridyl nitrogens; however, $\mathrm{t}_{1 / 2}$ values in these complex conditions are unknown. In the simple in vitro system, the reactions were therefore carried out between $70-100{ }^{\circ} \mathrm{C}$ for $3-10 \mathrm{~h}$, to activate the homolysis. Due to the poor solubility of heme in aqueous medium, dimethylsulfoxide was used as solvent. The reactions were monitored by UV-visible spectroscopy and LC-MS. After the given reaction time, NMR analysis of the crude reaction mixtures of alkoxyamines with heme was carried out, after the addition of 2-4 mole equivalents of $\mathrm{KCN}$ in order to generate a low spin Fe(III)-heme derivative.

Reaction of $\mathbf{1 a}, \mathbf{2 F}$ or $\mathbf{8 F}$ in the presence of heme. In preliminary assays, the reaction of $(R S / S R)-\mathbf{1 a}$ or $(R R / S S)$-1a with heme was carried out for $6 \mathrm{~h}$ at $80^{\circ} \mathrm{C}$, under argon, and exhibited the same results with both starting diastereomers. Monitoring by LC-MS indicated that heme was not modified $\left(t_{R}=10.3 \mathrm{~min}, \lambda_{\max }=405 \mathrm{~nm}, \mathrm{~m} / z=616 \mathrm{amu}\right.$ ), suggesting the absence of reaction on the heme macrocycle. Conversely, $(R R / S S)-\mathbf{1 a} /(R S / S R)-\mathbf{1 a}\left(t_{\mathrm{R}}=11.7\right.$ and $11.8 \mathrm{~min}$ for $(R R / S S)-\mathbf{1 a}$ and $(R S / S R)-\mathbf{1 a}$, respectively) completely disappeared upon reaction for $6 \mathrm{~h}$ at $80^{\circ} \mathrm{C}$, while a new chromatographic peak 
was detected at $t_{R}=13.7 \mathrm{~min}$, with $\mathrm{m} / z$ values of 295 and $317 \mathrm{amu}$, which was assigned to the nitroxide radical $\left(\mathrm{M}+\mathrm{H}^{+}\right.$and $\mathrm{M}+\mathrm{Na}^{+}$, respectively) derived from $(R R / S S)-\mathbf{1 a} /(R S / S R)-\mathbf{1 a}$. Detection of the nitroxyl radical indicated that homolysis of the alkoxy bond occurred, and that the corresponding alkyl radical (Figure 1) was generated in the medium. However, this radical was unable to react with heme to generate covalent heme-drug adducts.

When $(R S / S R)-\mathbf{2 F}$ or $(R R / S S)-\mathbf{2 F}$ reacted with heme under argon in DMSO- $d_{6}$, for $6 \mathrm{~h}$ at $95^{\circ} \mathrm{C}, \mathrm{NMR}$ analysis of the crude reaction mixture allowed characterization of $4^{\prime}$-ethyl terpyridine (compound 22, Scheme 5, route a), as the main product derived from the drug (>85-90 mol\% with respect to the terpyridine fragment). The ${ }^{1} \mathrm{H}$ and ${ }^{13} \mathrm{C}$ resonances of the ethyl- $\mathrm{CH}_{3}$ were detected at 1.30 and 15.1 ppm, respectively, while those of the ethyl- $\mathrm{CH}_{2}$ were detected at 2.85 and 28.3 ppm, respectively. The structure was confirmed by the HMBC correlation between the methylene protons (2.85 ppm) and $\mathrm{C}^{\prime} / \mathrm{C5}^{\prime}$ detected at $120.0 \mathrm{ppm}$, and correlation between the $\mathrm{H} 3^{\prime} / \mathrm{H}^{\prime}$ proton (8.33 ppm) and the methylene $\mathrm{CH}_{2}(28.3 \mathrm{ppm})$. The origin of the $\mathrm{H}^{\bullet}$ abstracted by 21 (maybe from the $\mathrm{R}_{1} \mathrm{R}_{2} \mathrm{NO}^{\bullet}$ fragment) was not investigated further. Beside $4^{\prime}$-ethyl terpyridine, all $\mathrm{Fe}$ (III)-heme protons were detected and assigned, similarly to the resonances of the starting heme, and with expected integral values. In particular, the four meso protons were detected as expected at 2.82, 1.21, 0.39, and -0.09 ppm, highly shielded due to the current cycle of this paramagnetic complex. The $\beta$-pyrrolic methyl substituents were detected as four singlets at 16.70, 16.27, 12.58, and $10.79 \mathrm{ppm}$; the vinyl $\mathrm{CH}$ were at 11.24 and $10.42 \mathrm{ppm}$, and the vinyl $\mathrm{CH}_{2}$ were at $-1.72,-2.25,-2.35$, and $-2.82 \mathrm{ppm}(4 \times 1 \mathrm{H})$; the propionate methylene were detected at $6.35,5.97,-0.37,-1.70 \mathrm{ppm}(4 \times 2 \mathrm{H})$. Thus, no modified porphyrin macrocycle could be detected. As in the case of $(R R / S S)-\mathbf{1 a}$ and $(R S / S R)-\mathbf{1 a}$, no coupling product between heme and the drug could be detected.

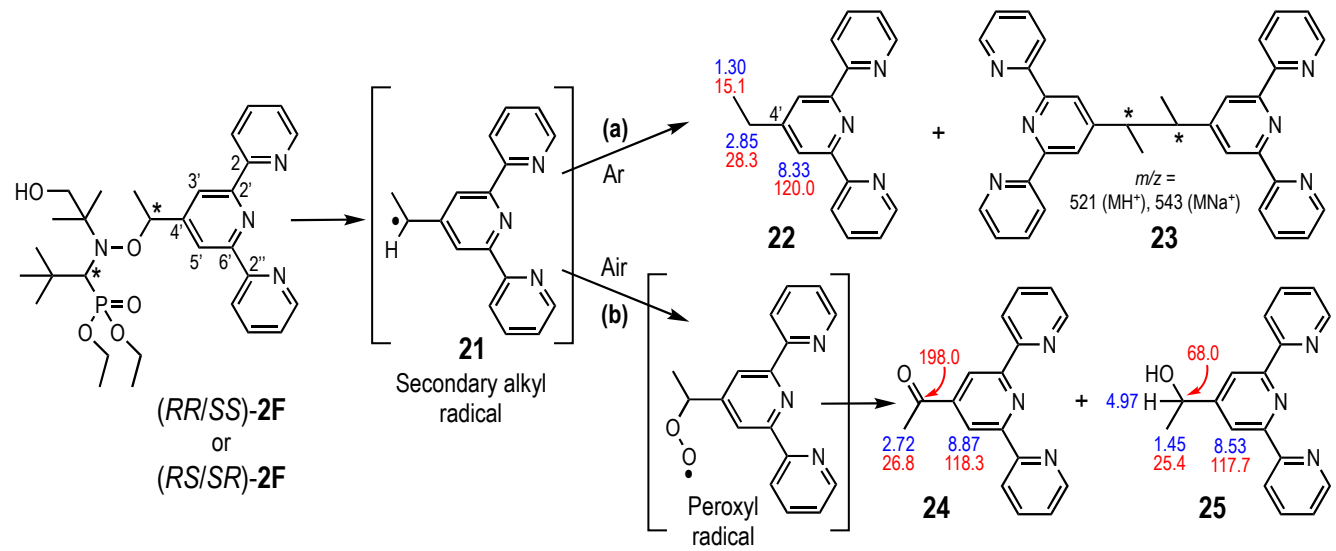

Scheme 5. Reaction of (RR/SS)-2F or (RS/SR)-2F with heme under inert atmosphere (route a) or in the presence of air (route b). The blue and red labels stand for the ${ }^{1} \mathrm{H}$ and ${ }^{13} \mathrm{C}-\mathrm{NMR}$ chemical shifts, respectively.

Analysis of this reaction mixture by LC-MS indicated that $(R R / S S)-\mathbf{2 F}$ and $(R S / S R)-\mathbf{2} \mathbf{F}$ completely disappeared in these reaction conditions $\left(t_{R}=13.5 \mathrm{~min}\right)$. The major drug derived product was detected at $4.7 \mathrm{~min}$, with $\mathrm{m} / \mathrm{z}$ values of $262.3 \mathrm{amu}\left(\mathrm{M}+\mathrm{H}^{+}\right)$and $284.3\left(\mathrm{M}+\mathrm{Na}^{+}\right)$, confirming the characterization of $4^{\prime}$-ethyl terpyridine 22 as the major product. Two other peaks were detected at 8.0 and $10.0 \mathrm{~min}$, each of them with $m / z=521.3\left(\mathrm{M}+\mathrm{H}^{+}\right)$and $543.3 \mathrm{amu}\left(\mathrm{M}+\mathrm{Na}^{+}\right)$. These $m / z$ values, and the isotopic profiles were consistent with the dimerization of the alkyl radical generated by homolysis of the $\mathrm{NO}-\mathrm{C}$ bond (Compound 23, Scheme 5). The detection of two chromatographic peaks is consistent with the existence of two diastereomeric racemates $((R R / S S)$ and $(R S / S R))$ expected for compound 23 . These results clearly indicated that, upon homolysis of these alkoxyamines under argon, the generated alkyl radical 21 abstracted $\mathrm{H}^{\bullet}$ to produce 22, or alternatively dimerized to produce $\mathbf{2 3}$, rather than to react with the porphyrin macrocycle. 
When $(R S / S R)-\mathbf{2 F}$ or $(R R / S S)-\mathbf{2} \mathbf{F}$ was homolyzed in the presence of heme under an air atmosphere (Scheme 5, route b), NMR analysis of the total reaction mixture allowed the detection of two terpyridine derivatives substituted at $\mathrm{C}^{\prime}, \mathbf{2 4}$ and 25. The structure of the secondary alcohol 25 was assessed by the detection of $\mathrm{CH}_{3}-\mathrm{CH}(\mathrm{OH})$ - at $4.97 \mathrm{ppm}$ in the proton, and $68.0 \mathrm{ppm}$ in ${ }^{13} \mathrm{C}-\mathrm{NMR}$, respectively. The $\mathrm{CH}_{3}-\mathrm{CH}(\mathrm{OH})$ - was detected at $1.45 \mathrm{ppm}$ in the proton, and $25.4 \mathrm{ppm}$ in ${ }^{13} \mathrm{C}-\mathrm{NMR}$, respectively. HMBC correlations between the $\mathrm{CH}(\mathrm{OH})$ signal $(4.97 \mathrm{ppm})$ and $\mathrm{C}^{\prime} / \mathrm{C}^{\prime}$ (117.7 ppm) on the one hand, and between the $\mathrm{H}^{\prime} / \mathrm{H}^{\prime}(8.53 \mathrm{ppm})$ and the $\mathrm{CH}(\mathrm{OH})(68.0 \mathrm{ppm})$ on the other hand, confirmed the structure. The $4^{\prime}$-acetyl terpyridine, 24, was characterized by the carbonyl detected at $198.0 \mathrm{ppm}$, the methyl detected at $2.72 \mathrm{ppm}$ and $26.8 \mathrm{ppm}$ in ${ }^{1} \mathrm{H}$ and ${ }^{13} \mathrm{C}$, respectively, and confirmed by the $\mathrm{HMBC}$ correlation of the carbonyl-C with $\mathrm{H}^{\prime}$ and $\mathrm{H}^{\prime}$ (8.87 ppm) and with $\mathrm{CH}_{3}(2.72 \mathrm{ppm})$. The other protons and carbons of compounds, 24 and 25, were all detected, and were rather similar for both compounds. The alcohol 25 and ketone 24 derivatives are likely generated by the trapping of dioxygen by the secondary alkyl radical 21 to yield a peroxyl radical, followed by the dimerization of the peroxyl, and subsequent cleavage to the corresponding alkoxyl radical (Figure S16) [38]. The two products, 24 and 25 , were also generated by thermal homolysis of the alkoxyamine in the same conditions, but in the absence of heme.

The alkoxyamine 8F contains the 4-hydroxy-tetramethylpiperidine- $N$-oxyl (8, Figure S1A) instead of the phosphonate derivative, 2 , associated with the 1-(4'-terpyridyl) radical $\mathbf{F}$. Its antimalarial activity is the highest in the tested series, with an $\mathrm{IC}_{50}$ value of $0.14 \mu \mathrm{M}$ on the P. falciparum line FcB1-Columbia, $(\sim 1 \mu \mathrm{M}$ on the F32 strains) but a weak selectivity index of 0.5 (Table 1 , Table S1). The reactivity of $\mathbf{8 F}$ with heme was evaluated under aerobic conditions in DMSO- $d_{6}$, in similar conditions as reported above for 2F. Monitoring of the reaction for $3 \mathrm{~h}$ by LC-MS indicated that heme was not significatively modified, while $85-90 \%$ of the starting amount of $\mathbf{8 F}$ disappeared. After the addition of KCN in the crude reaction mixture, NMR analysis allowed for the characterization of unchanged low spin $\mathrm{Fe}$ (III)-heme along with $4^{\prime}$-acetyl terpyridine (24, Scheme 5, chemical shifts of $\mathrm{CH}_{3}-\mathrm{CO}$ - at 2.78 and $27.7 \mathrm{ppm}$ in ${ }^{1} \mathrm{H}$ and ${ }^{13} \mathrm{C}$, respectively, $\mathrm{CO}$ at $198.4 \mathrm{ppm}, \mathrm{HC}^{\prime} / \mathrm{HC}^{\prime}$ at 8.83 and $118.2 \mathrm{ppm}, 82 \%$ of the products containing the terpyridine moiety). Notably, the $4^{\prime}$-acetyl terpyridine was partly deuterated on the methyl group, giving rise to a $-\mathrm{CH}_{2} \mathrm{D}$ residue. This was assessed by the detection of the $-\mathrm{CH}_{2} \mathrm{D}$ at $2.76 \mathrm{ppm}$, as a triplet with ${ }^{2} J_{\mathrm{HD}}=1.8 \mathrm{~Hz}$, that was correlated in HSQC with the resonance of $\mathrm{CH}_{2} \mathrm{D}$ at $27.7 \mathrm{ppm}$. The mole ratio $24 / 24-d$ was $45 / 55$. The mechanism of introduction of a deuterium atom from DMSO- $d_{6}$ within $4^{\prime}$-acetyl terpyridine was not investigated further; however, this reaction clearly indicates that the alkyl radical resulting from the homolysis of the alkoxyamine $\mathrm{NO}-\mathrm{C}$ bond does not efficiently target heme.

Two minor products containing the terpyridine residue were also identified: unreacted starting material $8 \mathrm{~F}(8 \%)$, and a product that was tentatively identified as 25 , Scheme 5 (chemical shifts of $\mathrm{CH}(\mathrm{OH})$ at $4.94 \mathrm{ppm}$ and $67.8 \mathrm{ppm}$ in ${ }^{1} \mathrm{H}$ and ${ }^{13} \mathrm{C}$, respectively, $\mathrm{CH}_{3}-\mathrm{CH}(\mathrm{OH})-$ at $1.42 \mathrm{ppm}, \mathrm{HC}^{\prime} / \mathrm{HC}^{\prime}$ at 8.45 and $118.2 \mathrm{ppm}, 10 \%$ ). These results evidence that the alkoxyamine $8 \mathrm{~F}$ did not react with heme to produce heme-alkyl covalent adducts. This was confirmed by a diffusion ordered spectroscopy (DOSY) NMR analysis: the diffusion coefficients D were found to be $(1.9 \pm 0.1) \times 10^{-10} \mathrm{~m}^{2} / \mathrm{s},(2.6 \pm 0.1)$ $\times 10^{-10} \mathrm{~m}^{2} / \mathrm{s}$, and $(2.1 \pm 0.1) \times 10^{-10} \mathrm{~m}^{2} / \mathrm{s}$ for $8 \mathrm{~F}, 24$ and 25 , respectively, significantly higher than the $(1.4 \pm 0.1) \times 10^{-10} \mathrm{~m}^{2} / \mathrm{s}$ value of $\mathrm{D}$ for heme, indicating that the reaction products of $8 \mathrm{~F}$ in the presence of heme did not contain the heme moiety.

Consequently, in aerobic conditions, the reaction of the alkyl radical 21 with dioxygen is expected to occur more quickly than with the porphyrin macrocycle of heme, a reaction that was not detected in vitro. In fact, the steric hindrance of the secondary alkyl radical 21 may prevent it from accessing the meso carbon of the heme cycle. Calculation by the B3lyp/3-21G* method of the alkylation free energy $\Delta G$ for the alkylation of heme by 21 was found to be $+56.2 \mathrm{kcal} / \mathrm{mol}$ and $+58.4 \mathrm{kcal} / \mathrm{mol}$ at $\mathrm{C} \beta$ and $C \delta$, respectively, indicating that the coupling between the two moieties is unfavorable (Scheme 5). In addition, in the computed heme-drug adduct, the heme residue is strongly distorted from planarity, which is the preferred geometry of the highly aromatic heme macrocycle, and the dihedral angle 
between two trans pyrrole cycles is between $147-149^{\circ}$, instead of $\sim 180^{\circ}$, the normal value in a planar heme residue (Scheme 6).

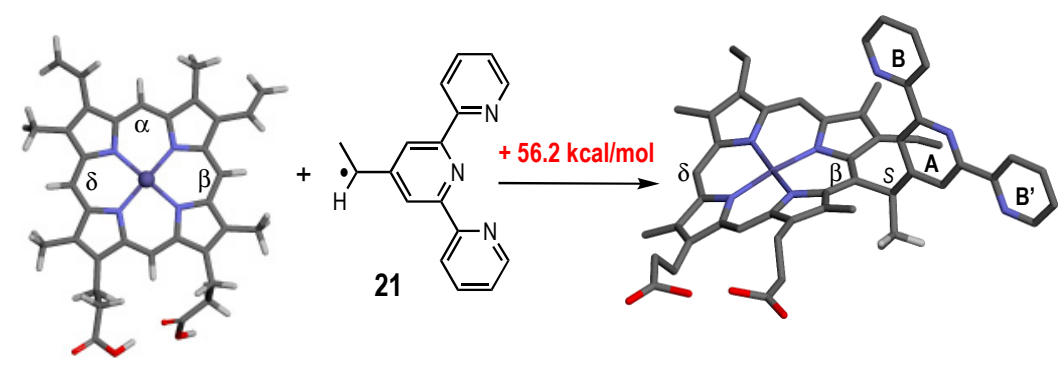

Scheme 6. Computed free energy (B3lyp/3-21G*) of alkylation of heme at the $\beta$-meso position, by the alkyl radical derived from the homolysis of $(R R / S S)-2 \mathrm{~F}$ or $(R S / S R)-2 \mathrm{~F}$.

Alkylation of heme within the parasite can therefore not be considered to be responsible for the antimalarial activity of alkoxyamines containing the alkyl radical $\mathbf{F}$, namely $(R S / S R)-2 \mathbf{F},(R R / S S)-2 \mathbf{F}$, or $\mathbf{8 F}$. Conversely, production of the alkyl radical in an oxygen rich biological medium may result in the generation of the peroxyl radical (Scheme 5, route b) which is able to induce damaging radical chain peroxidations. These non-selective peroxidations may be responsible for both antimalarial activity and cytotoxicity of these alkoxyamines, explaining a moderate selectivity index of these drugs (ratio Vero cells $/ P$. falciparum $=1$ or 0.5 for $\mathbf{2 F}$ and $\mathbf{8 F}$, respectively, Table 1 ).

Moreover, the computational study indicates that the main steric hindrance preventing heme alkylation by the radical $\mathbf{2 1}$ was generated by cycle A of terpyridine (Scheme 6), while cycles B and B' do not take a significant part in the steric hindrance. This suggests that the result should be similar with any alkoxyamine having an aryl substituent on the $C$ (structure $\left(\mathrm{R}_{1}, \mathrm{R}_{2}\right)-\mathrm{NO}-\mathrm{C}$-Ar). The linker between the putative alkylating $C^{\bullet} 21$ and the pyridine, terpyridine, or any aromatic group should be long enough (Scheme 7), to enable the radical to insert between the $\beta$-pyrrolic substituents and alkylate heme at meso carbons. In addition, if the $\mathrm{Z}$ substituent of alkoxyamine is able to behave as a ligand of the iron heme, it is expected to improve the selectivity of alkoxyamines for Plasmodium, and thus improve the selectivity index of the drugs. Such drugs are currently under investigation.

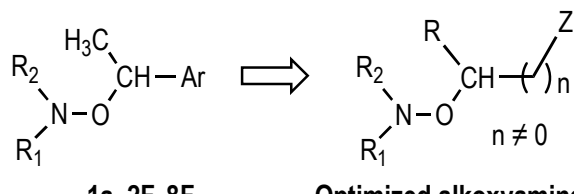

1a, $2 \mathrm{~F}, 8 \mathrm{~F} \quad$ Optimized alkoxyamines

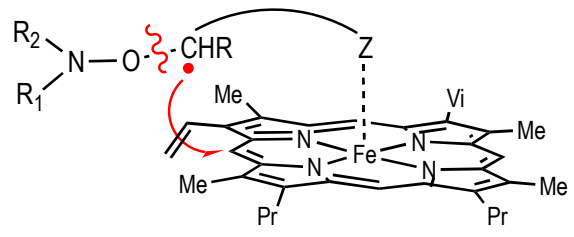

Scheme 7. Optimized structure of alkoxyamines.

Notably, we focused here on the reactivity of the secondary alkyl radical generated by homolysis of the NO-C bond of alkoxyamines. This homolysis also produces the $\left(\mathrm{R}_{1}, \mathrm{R}_{2}\right)-\mathrm{NO}{ }^{\bullet}$ nitroxyl radical (=aminoxyl radical), which is expected to interfere with redox metabolism in vivo [39,40]. For instance, 4-Hydroxy-2,2,6,6-tetramethylpiperidine-N-oxyl (tempol) is reported to limit the formation of toxic hydroxyl radicals produced by Fenton reactions in cell and animal studies. When administered intravenously, tempol caused rapid and reversible dose-dependent reductions in blood pressure in rodent models of hypertension [41]. However, this issue is beyond the scope of the present report. 


\section{Conclusions}

Among the series of alkoxyamines which have been evaluated against P. falciparum and S. mansoni, several of them exhibit significant activities ( IC $_{50}$ less than $500 \mathrm{nM}$ against Plasmodium and mean time to kill the $S$. mansoni worms of $1 \mathrm{~h}$ ). The antiparasitic activity of these drugs is probably not related to a hypothetical heme alkylation since such a pathway has not been evidenced in vitro. Even with the large set of data obtained with these alkoxyamines, it has not been possible to evidence a straightforward relationship between the structure and the activity of the drugs. However, both the desired antiparasitic activity and the cytotoxicity are likely to be due to similar radical pathways, thus leading to rather poor selectivity index values.

In order to separate antiparasitic activity and cytotoxicity, and consequently improve the selectivity of the drugs, it will be important to develop a new series of heme-targeting alkoxyamines that possess a chemical function able to activate the homolysis of the NO-C bond upon coordination on the heme iron. In addition, while coordinating onto the iron, these molecules are sterically designed to generate the $\mathrm{C}$-centered radical in close vicinity of the alkylable heme $\mathrm{C}_{\text {meso }}$ positions (Scheme 6).

\section{Materials and Methods}

\subsection{Synthesis of Alkoxyamines}

\subsubsection{Methods}

Analytical thin layer chromatographies (TLC) were carried out using Merck Kieselgel 60 F254 plates; spots were visualized upon exposure to UV light or stained with phosphomolybdic acid solution in EtOH and heat revealed. Purifications were performed on a Reveleris ${ }^{\circledR} \mathrm{X} 2$ flash chromatography system (BUCHI, Flawil, Switzerland) on Merck Kieselgel 60 (230-400 mesh). All experiments were performed in anhydrous conditions and under an inert atmosphere using argon and, except where stated, using dried apparatus and employing standard techniques for handling air-sensitive materials. ${ }^{1} \mathrm{H},{ }^{13} \mathrm{C}$, and ${ }^{31} \mathrm{P}-\mathrm{NMR}$ spectra were recorded in $\mathrm{CDCl}_{3}$ on an Avance 300 Bruker spectrometer working at $300.13 \mathrm{MHz}$ in proton. Chemical shifts $(\delta, \mathrm{ppm})$ were reported using residual non-deuterated solvents as the internal reference for ${ }^{1} \mathrm{H}$ and ${ }^{13} \mathrm{C}$-NMR spectra, and using an internal capillary filled with $85 \% \mathrm{H}_{3} \mathrm{PO}_{4}$ for ${ }^{31} \mathrm{P}-\mathrm{NMR}$ spectra.

The purity of final alkoxyamines $(R S / S R)-$ and $(R R / S S)-2 \mathbf{F},-4 \mathbf{F},-6 \mathbf{F},-2 \mathrm{G},-6 \mathbf{G}$, and $(R / S)-8 \mathbf{F}$, was evaluated to be higher than $97-98 \mathrm{~mol} \%$ because there was no other significant peak than those of the targeted compound in the ${ }^{1} \mathrm{H}-\mathrm{NMR}$ spectra recorded in the following conditions. Acquisition: $5-7 \mathrm{mg}$ of alkoxyamine was dissolved in $0.5 \mathrm{~mL}$ of $\mathrm{CDCl}_{3}$; pulse program: zg30; sample temperature: $300 \mathrm{~K} \pm 0.1 \mathrm{~K}$; data points (acquired) = 32,768; zero-filling SI = 65,536; dummy scans: 2-4; scans NS = 16-32; pulse width $\mathrm{P} 1=14.0 \mu \mathrm{s}$; relaxation delay $\mathrm{D} 1=1 \mathrm{~s}$; acquisition time $\mathrm{AQ}=5.45 \mathrm{~s}$; spectral window $\mathrm{SW}=6009.6 \mathrm{~Hz}$; transmitter offset $=300.13 \mathrm{MHz}$; pre-acquisition delay $\mathrm{DE}=10.0 \mu \mathrm{s}$. Processing: line broadening $\mathrm{LB}=0-0.3 \mathrm{~Hz}$; automatic phasing; 5th order polynomial baseline correction. The spectra are provided as Supporting Information.

High-resolution mass spectra (HRMS) were recorded on a SYNAPT G2 HDMS (Waters) spectrometer equipped with a pneumatically assisted atmospheric pressure ionization source (API). Positive mode electrospray ionization was used on samples: electrospray voltage (ISV): $2800 \mathrm{~V}$; opening voltage (OR): $20 \mathrm{~V}$; nebulizer gas pressure (nitrogen): $800 \mathrm{~L} \mathrm{~h}^{-1}$.

\subsubsection{Syntheses and Characterization}

$4^{\prime}$-(1-Bromoethyl)-2,2':6', $2^{\prime \prime}$-terpyridine (18): A mixture of $4^{\prime}$-vinylterpyridine $(1.40 \mathrm{~g}, 5.40 \mathrm{mmol})$ and palladium on activated carbon $(60 \mathrm{mg}, 0.57 \mathrm{mmol}, 0.1 \mathrm{eq}$.) in ethyl acetate $(20 \mathrm{~mL})$ was stirred at room temperature for $4 \mathrm{~h}$ under hydrogen atmosphere. The reaction mixture was filtered and concentrated under reduced pressure to give compound $4^{\prime}$-ethyl-2,2':6', $2^{\prime \prime}$-terpyridine, which was used in the next step without any further purification $(1.36 \mathrm{~g}, 96 \%) .{ }^{1} \mathrm{H}-\mathrm{NMR}\left(300 \mathrm{MHz}, \mathrm{CDCl}_{3}\right): \delta 8.69(\mathrm{~d}, \mathrm{~J}=4.7 \mathrm{~Hz}$, 
$2 \mathrm{H}) ; 8.61(\mathrm{~d}, J=8.0 \mathrm{~Hz}, 2 \mathrm{H}) ; 8.32(\mathrm{~s}, 2 \mathrm{H}) ; 7.83(\mathrm{td}, J=7.7,1.6 \mathrm{~Hz}, 2 \mathrm{H}) ; 7.32-7.28(\mathrm{~m}, 2 \mathrm{H}) ; 2.83(\mathrm{q}$, $J=7.6 \mathrm{~Hz}, 2 \mathrm{H}) ; 1.37(\mathrm{t}, J=7.6 \mathrm{~Hz}, 3 \mathrm{H}) .{ }^{13} \mathrm{C}-\mathrm{NMR}\left(75 \mathrm{MHz}, \mathrm{CDCl}_{3}\right): \delta 156.5 ; 155.3 ; 155.1 ; 149.0 ; 136.7$; $123.6 ; 121.3 ; 120.6 ; 28.7 ; 14.5$.

$4^{\prime}$-Ethyl-2,2': $6^{\prime}, 2^{\prime \prime}$-terpyridine ( $\left.1.00 \mathrm{~g}, 3.83 \mathrm{mmol}\right), \mathrm{N}$-bromosuccinimide ( $0.75 \mathrm{~g}, 4.21 \mathrm{mmol}, 1.1 \mathrm{eq}$.) and benzoyl peroxide ( $93 \mathrm{mg}, 0.38 \mathrm{mmol}, 0.1$ eq.) were dissolved in $\mathrm{CCl}_{4}(20 \mathrm{~mL})$ and refluxed for $6 \mathrm{~h}$. After cooling, the reaction mixture was subjected to filtration. The filtrate was washed with saturated aqueous solution of sodium bicarbonate and saturated aqueous solution of sodium chloride, dried over magnesium sulfate and concentrated under reduced pressure. The crude product was chromatographed on silica gel deactivated by $10 \%$ TEA using a 9/1: petroleum ether/ethyl acetate mixture as the eluting solvent. Removal of the solvent under reduced pressure yielded $4^{\prime}$-(1-bromoethyl)-2,2': $66^{\prime}, 2^{\prime \prime}$-terpyridine 18 as the white solid $(0.71 \mathrm{~g}, 55 \%)$. ${ }^{1} \mathrm{H}-\mathrm{NMR}\left(300 \mathrm{MHz}, \mathrm{CDCl}_{3}\right)$ : $\delta 8.60(\mathrm{~d}, J=4.1 \mathrm{~Hz}, 2 \mathrm{H}) ; 8.49(\mathrm{~d}, J=8.0 \mathrm{~Hz}, 2 \mathrm{H}) ; 8.42(\mathrm{~s}, 2 \mathrm{H}) ; 7.73(\mathrm{td}, J=7.8,1.7 \mathrm{~Hz}, 2 \mathrm{H}) ; 7.24-7.19(\mathrm{~m}$, $2 \mathrm{H}) ; 5.17(\mathrm{q}, J=6.9 \mathrm{~Hz}, 1 \mathrm{H}) ; 2.05(\mathrm{~d}, J=6.9 \mathrm{~Hz}, 2 \mathrm{H}) .{ }^{13} \mathrm{C}-\mathrm{NMR}\left(101 \mathrm{MHz}, \mathrm{CDCl}_{3}\right): \delta 156.1 ; 155.8 ; 153.7$; 149.1; 136.9; 124.0; 121.4; 119.0; 46.8; 26.1. HRMS (ESI) cal. for $\mathrm{C}_{17} \mathrm{H}_{15} \mathrm{~N}_{3} \mathrm{Br}^{+}: 340.0444[\mathrm{M}+\mathrm{H}]^{+}$; found: 340.0441.

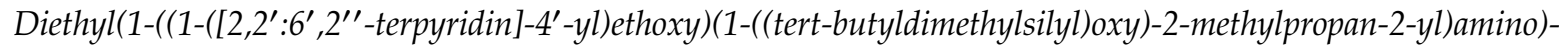
2,2-dimethylpropyl)phosphonate ((RR/SS)-6F and (RS/SR)-6F)): To a stirred suspension of $\mathrm{CuBr}(0.43 \mathrm{~g}$, $2.94 \mathrm{mmol}, 1.0$ eq.) and $\mathrm{Cu}(0.37 \mathrm{~g}, 5.88 \mathrm{mmol}, 2.0$ eq. $)$ in degassed benzene $(10 \mathrm{~mL})$ was added $\mathrm{N}, \mathrm{N}, \mathrm{N}^{\prime}, \mathrm{N}^{\prime \prime}, \mathrm{N}^{\prime \prime}$-pentamethyldiethylenetriamine $(0.61 \mathrm{~mL}, 2.94 \mathrm{mmol}, 1.0$ eq.). The resulting mixture was stirred under argon at room temperature for $10 \mathrm{~min}$, then a solution of the bromide $\mathbf{1 8}(1.00 \mathrm{~g}$, $2.94 \mathrm{mmol}$ ) and SG1-OTBS (1.37 g, $3.23 \mathrm{mmol}, 1.1 \mathrm{eq}$.) in degassed benzene (10 mL) was slowly added. The mixture was stirred overnight under argon $(15 \mathrm{~h})$. It was then diluted with DCM, quenched and washed several times with saturated aqueous ammonia solution, water and brine. After drying with $\mathrm{MgSO}_{4}$, filtration and concentration, the crude product was chromatographed on silica gel deactivated by $10 \%$ TEA using a 15/85: petroleum ether/diethyl ether mixture as the eluting solvent to give the major product $(R S / S R)-6 \mathrm{~F}(1.10 \mathrm{~g})$ and the minor product $(R R / S S)-6 \mathrm{~F}(510 \mathrm{mg})$ as a white solid $(75 \%)$. (RS/SR)-6F: ${ }^{31} \mathrm{P}-\mathrm{NMR}\left(162 \mathrm{MHz}, \mathrm{CDCl}_{3}\right): \delta 24.67 .{ }^{1} \mathrm{H}-\mathrm{NMR}\left(300 \mathrm{MHz}, \mathrm{CDCl}_{3}\right): \delta 8.68(\mathrm{dd}, J=4.8$, $0.8 \mathrm{~Hz}, 2 \mathrm{H}) ; 8.58(\mathrm{~d}, J=8.0 \mathrm{~Hz}, 2 \mathrm{H}) ; 8.49(\mathrm{~s}, 2 \mathrm{H}) ; 7.83(\mathrm{td}, J=7.8,1.8 \mathrm{~Hz}, 2 \mathrm{H}) ; 7.30(\mathrm{ddd}, J=7.5,4.8$, $1.1 \mathrm{~Hz}, 2 \mathrm{H}) ; 5.42(\mathrm{q}, J=6.5 \mathrm{~Hz}, 1 \mathrm{H}) ; 4.00-3.85(\mathrm{~m}, 2 \mathrm{H}) ; 3.79(\mathrm{~d}, J=26.8 \mathrm{~Hz}, 3 \mathrm{H}) ; 3.72-3.61(\mathrm{~m}, 2 \mathrm{H}) ; 1.66$ $(\mathrm{d}, J=6.6 \mathrm{~Hz}, 3 \mathrm{H}) ; 1.26(\mathrm{~s}, 6 \mathrm{H}) ; 1.24(\mathrm{~s}, 9 \mathrm{H}), 1.21(\mathrm{~d}, J=7.1 \mathrm{~Hz}, 3 \mathrm{H}) ; 0.95-0.90(\mathrm{~m}, 12 \mathrm{H}) ; 0.11(\mathrm{~s}, 6 \mathrm{H})$. ${ }^{13} \mathrm{C}-\mathrm{NMR}\left(75 \mathrm{MHz}, \mathrm{CDCl}_{3}\right): \delta 156.3 ; 155.4 ; 154.7 ; 149.1 ; 136.6 ; 123.5 ; 121.1 ; 119.3 ; 69.6(\mathrm{~d}, J=138.8 \mathrm{~Hz})$; 69.0; 65.5; $61.8(\mathrm{~d}, J=6.7 \mathrm{~Hz}) ; 59.2(\mathrm{~d}, J=7.6 \mathrm{~Hz}) ; 35.5(\mathrm{~d}, J=5.1 \mathrm{~Hz}) ; 30.6(\mathrm{~d}, J=5.9 \mathrm{~Hz}) ; 25.9 ; 23.8 ; 22.5$; 21.6; $18.3 ; 16.3(\mathrm{~d}, J=5.8 \mathrm{~Hz}) ; 16.1(\mathrm{~d}, J=7.0 \mathrm{~Hz}) ;-5.4 ;-5.5$. HRMS (ESI) cal. for $\mathrm{C}_{36} \mathrm{H}_{58} \mathrm{~N}_{4} \mathrm{O}_{5} \mathrm{PSi}^{+}$: 685.3909 [M + H] $]^{+}$; found: 685.3909. (RR/SS)-6F: ${ }^{31} \mathrm{P}-\mathrm{NMR}\left(162 \mathrm{MHz}, \mathrm{CDCl}_{3}\right): \delta 25.99 .{ }^{1} \mathrm{H}-\mathrm{NMR}$ $\left(300 \mathrm{MHz}, \mathrm{CDCl}_{3}\right): \delta 8.69(\mathrm{dd}, J=4.6,0.7 \mathrm{~Hz}, 2 \mathrm{H}) ; 8.62(\mathrm{~d}, J=8.0 \mathrm{~Hz}, 2 \mathrm{H}) ; 8.44(\mathrm{~s}, 2 \mathrm{H}) ; 7.85(\mathrm{td}, J=7.7$, $1.8 \mathrm{~Hz}, 2 \mathrm{H}) ; 7.32(\mathrm{ddd}, J=7.4,4.8,1.0 \mathrm{~Hz}, 2 \mathrm{H}) ; 5.20(\mathrm{q}, J=6.6 \mathrm{~Hz}, 1 \mathrm{H}) ; 4.53-4.33(\mathrm{~m}, 2 \mathrm{H}) ; 4.16-3.97$ $(\mathrm{m}, 2 \mathrm{H}) ; 3.73(\mathrm{~d}, J=26.2 \mathrm{~Hz}, 1 \mathrm{H}) ; 3.22(\mathrm{q}, J=9.9 \mathrm{~Hz}, 2 \mathrm{H}) ; 1.70(\mathrm{~d}, J=6.8 \mathrm{~Hz}, 3 \mathrm{H}) ; 1.47(\mathrm{t}, J=7.1 \mathrm{~Hz}$, $3 \mathrm{H}) ; 1.33(\mathrm{t}, J=7.1 \mathrm{~Hz}, 3 \mathrm{H}) ; 1.26(\mathrm{~s}, 9 \mathrm{H}) ; 0.95(\mathrm{~s}, 3 \mathrm{H}) ; 0.93(\mathrm{~s}, 3 \mathrm{H}), 0.73(\mathrm{~s}, 9 \mathrm{H}) ;-0.28(\mathrm{~s}, 3 \mathrm{H}) ;-0.30(\mathrm{~s}$, $3 \mathrm{H}) .{ }^{13} \mathrm{C}-\mathrm{NMR}\left(75 \mathrm{MHz}, \mathrm{CDCl}_{3}\right): \delta 156.6 ; 156.2 ; 155.6 ; 149.1 ; 136.7 ; 123.6 ; 121.1 ; 118.8 ; 70.6 ; 69.7(\mathrm{~d}$, $J=139.0 \mathrm{~Hz}) ; 65.6 ; 62.0(\mathrm{~d}, J=6.3 \mathrm{~Hz}) ; 58.9(\mathrm{~d}, J=7.5 \mathrm{~Hz}) ; 35.8(\mathrm{~d}, J=6.0 \mathrm{~Hz}) ; 29.8(\mathrm{~d}, J=5.8 \mathrm{~Hz}) ; 25.7$; 24.8; 23.9; 22.7; 18.0; $16.8(\mathrm{~d}, J=5.5 \mathrm{~Hz}) ; 16.2(\mathrm{~d}, J=6.9 \mathrm{~Hz}) ;-5.8 ;-5.9$. HRMS (ESI) calculated for $\mathrm{C}_{36} \mathrm{H}_{58} \mathrm{~N}_{4} \mathrm{O}_{5} \mathrm{PSi}^{+}$: 685.3909 [M + H] $]^{+}$; found: 685.3910 .

Diethyl(1-((1-([2,2':6', 2' '-terpyridin]-4'-yl)ethoxy)(1-hydroxy-2-methylpropan-2-yl)amino)-2,2-dimethylpropyl) phosphonate $(R S / S R)-2 \mathrm{~F})$ : To a solution of compound $(R S / S R)-6 \mathrm{~F}(0.50 \mathrm{~g}, 0.73 \mathrm{mmol})$ in dry THF $(10 \mathrm{~mL})$ was added $\mathrm{HF} / \mathrm{Py}(0.50 \mathrm{~mL})$ at $0{ }^{\circ} \mathrm{C}$, and the mixture was stirred at room temperature for $12 \mathrm{~h}$. The reaction was quenched by the addition of a saturated solution of $\mathrm{NaHCO}_{3}(20 \mathrm{~mL})$ to $\mathrm{pH} 8$, extracted with DCM and washed with water and brine. The combined organic phase was dried with $\mathrm{MgSO}_{4}$ and then concentrated under reduced pressure. The crude product was chromatographed on silica gel deactivated by $10 \%$ TEA using a 10\% ethyl acetate in a diethyl ether mixture as the eluting 
solvent. Removal of the solvent under reduced pressure yielded compound (RS/SR)-2F as the white solid (360 mg, 85\%). (RS/SR)-2F: ${ }^{31} \mathrm{P}-\mathrm{NMR}\left(162 \mathrm{MHz}, \mathrm{CDCl}_{3}\right): \delta 27.09 .{ }^{1} \mathrm{H}-\mathrm{NMR}\left(300 \mathrm{MHz}, \mathrm{CDCl}_{3}\right)$ : $\delta 8.66(\mathrm{~d}, J=4.1 \mathrm{~Hz}, 2 \mathrm{H}) ; 8.54(\mathrm{~d}, J=7.9 \mathrm{~Hz}, 2 \mathrm{H}) ; 8.41(\mathrm{~s}, 2 \mathrm{H}) ; 7.78(\mathrm{t}, J=7.3 \mathrm{~Hz}, 2 \mathrm{H}) ; 7.30-7.22(\mathrm{~m}$, $2 \mathrm{H}) ; 5.23(\mathrm{q}, J=6.5 \mathrm{~Hz}, 1 \mathrm{H}) ; 4.06-3.80(\mathrm{~m}, 5 \mathrm{H}) ; 3.63-3.42(\mathrm{~m}, 2 \mathrm{H}) ; 1.62(\mathrm{~d}, J=6.5 \mathrm{~Hz}, 3 \mathrm{H}) ; 1.30(\mathrm{~s}, 3 \mathrm{H})$; $1.18-1.12(\mathrm{~m}, 15 \mathrm{H}) ; 0.95(\mathrm{t}, J=7.0 \mathrm{~Hz}, 3 \mathrm{H}) .{ }^{13} \mathrm{C}-\mathrm{NMR}\left(75 \mathrm{MHz}, \mathrm{CDCl}_{3}\right): \delta 156.2 ; 155.4 ; 154.6 ; 149.2$; 136.7; 123.6; 121.3; 118.6; $69.3(\mathrm{~d}, J=134.8 \mathrm{~Hz}) ; 67.4 ; 64.7 ; 62.1(\mathrm{~d}, J=6.5 \mathrm{~Hz}) ; 61.1(\mathrm{~d}, J=8.0 \mathrm{~Hz}) ; 35.3(\mathrm{~d}$, $J=3.7 \mathrm{~Hz}) ; 30.6(\mathrm{~d}, J=5.5 \mathrm{~Hz}) ; 26.6 ; 24.7 ; 21.9 ; 16.3(\mathrm{~d}, J=5.6 \mathrm{~Hz}) ; 15.9(\mathrm{~d}, J=6.4 \mathrm{~Hz})$. HRMS (ESI) calculated for $\mathrm{C}_{30} \mathrm{H}_{44} \mathrm{~N}_{4} \mathrm{O}_{5} \mathrm{P}^{+}$: $571.3044[\mathrm{M}+\mathrm{H}]^{+}$; found: 571.3047 .

Starting from $(R R / S S)-6 \mathbf{F}(0.51 \mathrm{~g}, 0.25 \mathrm{mmol})$, derivative $(R R / S S)-2 \mathrm{~F}(366 \mathrm{mg}, 85 \%)$ was prepared according to the same procedure used for the preparation of $(R S / S R)-2 \mathrm{~F}$. (RR/SS)-2F: ${ }^{31} \mathrm{P}-\mathrm{NMR}(162 \mathrm{MHz}$, $\left.\mathrm{CDCl}_{3}\right): \delta 27.20 .{ }^{1} \mathrm{H}-\mathrm{NMR}\left(300 \mathrm{MHz}, \mathrm{CDCl}_{3}\right): \delta 8.64(\mathrm{~d}, J=3.9 \mathrm{~Hz}, 2 \mathrm{H}) ; 8.55(\mathrm{~d}, J=7.9 \mathrm{~Hz}, 2 \mathrm{H}) ; 8.37(\mathrm{~s}$, $2 \mathrm{H}) ; 7.78(\mathrm{t}, J=7.5 \mathrm{~Hz}, 2 \mathrm{H}) ; 7.29-7.23(\mathrm{~m}, 2 \mathrm{H}) ; 5.10(\mathrm{q}, J=6.4 \mathrm{~Hz}, 1 \mathrm{H}) ; 4.26-4.10(\mathrm{~m}, 4 \mathrm{H}) ; 3.74-3.61(\mathrm{~m}$, $2 \mathrm{H}) ; 3.03(\mathrm{~d}, J=12.3 \mathrm{~Hz}, 1 \mathrm{H}) ; 1.60(\mathrm{~d}, J=6.6 \mathrm{~Hz}, 3 \mathrm{H}) ; 1.35(\mathrm{t}, J=7.2 \mathrm{~Hz}, 3 \mathrm{H}) ; 1.32(\mathrm{t}, J=7.1 \mathrm{~Hz}, 3 \mathrm{H})$; 1.19 (s, 3H); $1.16(\mathrm{~s}, 9 \mathrm{H}) ; 1.01(\mathrm{~s}, 3 \mathrm{H}) .{ }^{13} \mathrm{C}-\mathrm{NMR}\left(75 \mathrm{MHz}, \mathrm{CDCl}_{3}\right): \delta$ 156.2; 156.1; 155.6; 149.2; 136.7; 123.7; 121.2; 118.7; 85.5; $69.4(\mathrm{~d}, J=137.8 \mathrm{~Hz}) ; 67.0 ; 65.1 ; 62.2(\mathrm{~d}, J=6.4 \mathrm{~Hz}) ; 60.6(\mathrm{~d}, J=8.0 \mathrm{~Hz}) ; 35.7(\mathrm{~d}$, $J=4.7 \mathrm{~Hz}) ; 30.0(\mathrm{~d}, J=5.5 \mathrm{~Hz}) ; 27.3 ; 24.5 ; 24.1 ; 16.5(\mathrm{~d}, J=5.6 \mathrm{~Hz}) ; 16.3(\mathrm{~d}, J=6.6 \mathrm{~Hz})$. HRMS (ESI) calculated for $\mathrm{C}_{30} \mathrm{H}_{44} \mathrm{O}_{5} \mathrm{P}^{+}: 571.3044[\mathrm{M}+\mathrm{H}]^{+}$; found: 571.3044 .

Diethyl(1-((1-([2,2':6',2'"-terpyridin]-4'-yl)ethoxy)(2-methyl-1-oxopropan-2-yl)amino)-2,2-dimethylpropyl) phosphonate (RS/SR)-7F): A mixture of compound (RS/SR)-2F (200 mg, $0.35 \mathrm{mmol})$, Dess-Martin reagent ( $230 \mathrm{mg}, 0.53 \mathrm{mmol}, 1.5$ eq.) and sodium bicarbonate $\left(0.15 \mathrm{~g}, 1.75 \mathrm{mmol}, 5.0\right.$ eq.) in dry $\mathrm{CH}_{2} \mathrm{Cl}_{2}(20 \mathrm{~mL})$ was stirred at $0{ }^{\circ} \mathrm{C}$ for $4 \mathrm{~h}$. The reaction mixture was then diluted with $10 \% \mathrm{Na}_{2} \mathrm{~S}_{2} \mathrm{O}_{3}$ solution $(10 \mathrm{~mL})$ and then DCM-extracted. The combined organic layers were washed with water and brine, dried by $\mathrm{MgSO}_{4}$ and concentrated under reduced pressure. The crude product was chromatographed on silica gel deactivated by 10\% TEA using a 1/5 ethyl acetate/diethyl ether mixture as the eluting solvent. Removal of the solvent under reduced pressure yielded the corresponding aldehyde as a white solid (170 mg, 85\%). (RS/SR)-7F): ${ }^{31} \mathrm{P}-\mathrm{NMR}\left(162 \mathrm{MHz}, \mathrm{CDCl}_{3}\right): \delta 23.14 .{ }^{1} \mathrm{H}-\mathrm{NMR}\left(300 \mathrm{MHz}, \mathrm{CDCl}_{3}\right): \delta 9.90$ $(\mathrm{s}, 1 \mathrm{H}) ; 8.65(\mathrm{~d}, J=4.2 \mathrm{~Hz}, 2 \mathrm{H}) ; 8.52(\mathrm{~d}, J=7.9 \mathrm{~Hz}, 2 \mathrm{H}) ; 8.38(\mathrm{~s}, 2 \mathrm{H}) ; 7.78(\mathrm{td}, J=7.8,1.5 \mathrm{~Hz}, 2 \mathrm{H})$; 7.30-7.21 (m, 2H); $5.38(\mathrm{q}, J=6.4 \mathrm{~Hz}, 1 \mathrm{H}) ; 3.94-3.85(\mathrm{~m}, 2 \mathrm{H}) ; 3.71-3.63(\mathrm{~m}, 2 \mathrm{H}) ; 3.41(\mathrm{~d}, J=26.5 \mathrm{~Hz}$, $1 \mathrm{H}) ; 1.64(\mathrm{~d}, J=6.5 \mathrm{~Hz}, 3 \mathrm{H}) ; 1.33(\mathrm{~s}, 3 \mathrm{H}) ; 1.31(\mathrm{~s}, 3 \mathrm{H}) ; 1.18-1.13(\mathrm{~m}, 12 \mathrm{H}) ; 0.92(\mathrm{t}, J=7.1 \mathrm{~Hz}, 3 \mathrm{H})$. ${ }^{13} \mathrm{C}-\mathrm{NMR}\left(75 \mathrm{MHz}, \mathrm{CDCl}_{3}\right): \delta 202.6 ; 156.6 ; 155.5 ; 153.7 ; 149.1 ; 136.7 ; 123.6 ; 121.2 ; 119.1 ; 78.4 ; 71.0 ; 69.5$ $(\mathrm{d}, J=140.3 \mathrm{~Hz}) ; 62.0(\mathrm{~d}, J=6.9 \mathrm{~Hz}) ; 60.1(\mathrm{~d}, J=7.6 \mathrm{~Hz}) ; 35.4(\mathrm{~d}, J=4.8 \mathrm{~Hz}) ; 30.4(\mathrm{~d}, J=5.8 \mathrm{~Hz}) ; 22.8$; $21.8 ; 20.1 ; 16.2(\mathrm{~d}, J=5.4 \mathrm{~Hz}) ; 16.1(\mathrm{~d}, J=6.3 \mathrm{~Hz})$. HRMS (ESI) calculated for $\mathrm{C}_{30} \mathrm{H}_{42} \mathrm{~N}_{4} \mathrm{O}_{5} \mathrm{P}^{+}: 569.2887$ $[\mathrm{M}+\mathrm{H}]^{+}$; found: 569.2891 .

Starting from $(R R / S S)-2 \mathrm{~F}(201 \mathrm{mg}, 0.25 \mathrm{mmol}),(R R / S S)-7 \mathrm{~F}$ aldehyde derivative $(171 \mathrm{mg}, 85 \%)$ was prepared according to the same procedure used for the preparation of $(R S / S R)-7 \mathrm{~F} .{ }^{31} \mathrm{P}-\mathrm{NMR}(162 \mathrm{MHz}$, $\left.\mathrm{CDCl}_{3}\right): \delta$ 24.22. ${ }^{1} \mathrm{H}-\mathrm{NMR}\left(300 \mathrm{MHz}, \mathrm{CDCl}_{3}\right): \delta 9.36(\mathrm{~s}, 1 \mathrm{H}), 8.69(\mathrm{~d}, J=4.7 \mathrm{~Hz}, 2 \mathrm{H}), 8.63(\mathrm{~d}, J=8.0 \mathrm{~Hz}$, $2 \mathrm{H}), 8.39(\mathrm{~s}, 2 \mathrm{H}), 7.84(\mathrm{td}, J=7.8,1.7 \mathrm{~Hz}, 2 \mathrm{H}), 7.34-7.29(\mathrm{~m}, 2 \mathrm{H}), 5.30(\mathrm{q}, J=6.7 \mathrm{~Hz}, 1 \mathrm{H}), 4.49-4.21(\mathrm{~m}$, $2 \mathrm{H}), 4.20-3.99(\mathrm{~m}, 2 \mathrm{H}), 3.34(\mathrm{~d}, J=25.5 \mathrm{~Hz}, 1 \mathrm{H}), 1.68(\mathrm{~d}, J=6.8 \mathrm{~Hz}, 3 \mathrm{H}), 1.45(\mathrm{t}, J=7.1 \mathrm{~Hz}, 3 \mathrm{H}), 1.33$ $(\mathrm{t}, J=7.1 \mathrm{~Hz}, 3 \mathrm{H}), 1.27(\mathrm{~s}, 9 \mathrm{H}), 1.17(\mathrm{~s}, 3 \mathrm{H}), 0.93(\mathrm{~s}, 3 \mathrm{H}) .{ }^{13} \mathrm{C}-\mathrm{NMR}\left(75 \mathrm{MHz}, \mathrm{CDCl}_{3}\right): \delta 202.5 ; 156.1$; $155.7 ; 155.0 ; 149.1 ; 136.8 ; 123.7 ; 121.3 ; 118.9 ; 84.9 ; 71.5 ; 69.4(\mathrm{~d}, J=140.8 \mathrm{~Hz}) ; 62.2(\mathrm{~d}, J=6.5 \mathrm{~Hz}) ; 59.6$ $(\mathrm{d}, J=7.4 \mathrm{~Hz}) ; 35.7(\mathrm{~d}, J=5.5 \mathrm{~Hz}) ; 29.7(\mathrm{~d}, J=5.7 \mathrm{~Hz}) ; 23.8 ; 23.1 ; 19.6 ; 16.7(\mathrm{~d}, J=5.5 \mathrm{~Hz}) ; 16.3(\mathrm{~d}$, $J=6.6 \mathrm{~Hz}$ ). HRMS (ESI) calculated for $\mathrm{C}_{30} \mathrm{H}_{42} \mathrm{~N}_{4} \mathrm{O}_{5} \mathrm{P}^{+}$: $569.2887[\mathrm{M}+\mathrm{H}]^{+}$; found: 569.2888.

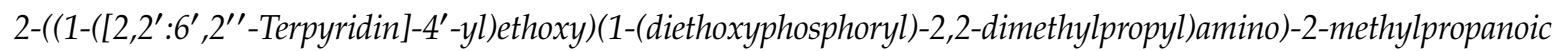
acid (RS/SR)-4F: A mixture of the aldehyde (RS/SR)-7F (150 mg, $0.26 \mathrm{mmol})$, sodium chlorite $(0.12 \mathrm{~g}, 5.0$ eq.), sodium dihydrogen phosphate $(250 \mathrm{mg}$, 8.0 eq.) and 2-methylbut-2-ene $(0.10 \mathrm{~mL})$ in $t$ - $\mathrm{BuOH}$ $(10 \mathrm{~mL})$ was stirred at room temperature for $2 \mathrm{~h}$. The reaction mixture was then diluted with water and then extracted by DCM. The combined organic layers were washed with water and brine, dried by $\mathrm{MgSO}_{4}$ and concentrated under reduced pressure. The crude product was chromatographed on silica 
gel deactivated by $10 \%$ TEA using DCM with $10 \% \mathrm{MeOH}$ as the eluting solvent. After removing the solvent, the TEA salt form was obtained. Then, using 1 eq of trifluoroacetic acid (TFA), the salt was transferred to its acid form (RS/SR)-4F as a white solid (131 mg, 80\%). (RS/SR)-4F: ${ }^{31} \mathrm{P}-\mathrm{NMR}(162 \mathrm{MHz}$, $\left.\mathrm{CDCl}_{3}\right): \delta 27.28 .{ }^{1} \mathrm{H}-\mathrm{NMR}\left(300 \mathrm{MHz}, \mathrm{CDCl}_{3}\right): \delta 8.70(\mathrm{~d}, J=4.2 \mathrm{~Hz}, 2 \mathrm{H}) ; 8.59(\mathrm{~d}, J=7.9 \mathrm{~Hz}, 2 \mathrm{H}) ; 8.40(\mathrm{~s}$, $1 \mathrm{H}) ; 7.84(\mathrm{t}, J=7.7 \mathrm{~Hz}, 2 \mathrm{H}) ; 7.34-7.28(\mathrm{~m}, 2 \mathrm{H}) ; 5.22(\mathrm{q}, J=6.4 \mathrm{~Hz}, 1 \mathrm{H}) ; 4.19-3.92(\mathrm{~m}, 4 \mathrm{H}) ; 3.44(\mathrm{~d}$, $J=25.1 \mathrm{~Hz}, 1 \mathrm{H}) ; 1.65(\mathrm{~d}, J=6.6 \mathrm{~Hz}, 3 \mathrm{H}) ; 1.60(\mathrm{~s}, 3 \mathrm{H}) ; 1.50(\mathrm{~s}, 3 \mathrm{H}) ; 1.28(\mathrm{t}, J=7.0 \mathrm{~Hz}, 3 \mathrm{H}) ; 1.10(\mathrm{~s}, 9 \mathrm{H})$; $1.05(\mathrm{t}, J=7.0 \mathrm{~Hz}, 3 \mathrm{H}) .{ }^{13} \mathrm{C}-\mathrm{NMR}\left(75 \mathrm{MHz}, \mathrm{CDCl}_{3}\right): \delta 175.6 ; 156.1 ; 155.4 ; 153.9 ; 149.1 ; 136.8 ; 123.7 ; 121.4$; $119.1 ; 81.1 ; 70.1 ; 69.0(\mathrm{~d}, J=139.7 \mathrm{~Hz}) ; 62.4(\mathrm{~d}, J=7.0 \mathrm{~Hz}) ; 61.5(\mathrm{~d}, J=7.9 \mathrm{~Hz}) ; 35.2(\mathrm{~d}, J=5.4 \mathrm{~Hz}) ; 30.0$ $(\mathrm{d}, J=5.8 \mathrm{~Hz}) ; 26.2 ; 25.9 ; 22.6 ; 16.3(\mathrm{~d}, J=5.6 \mathrm{~Hz}) ; 16.0(\mathrm{~d}, J=6.4 \mathrm{~Hz})$. HRMS (ESI) calculated for $\mathrm{C}_{30} \mathrm{H}_{42} \mathrm{~N}_{4} \mathrm{O}_{6} \mathrm{P}^{+}$: $585.2837[\mathrm{M}+\mathrm{H}]^{+}$; found: 585.2836 .

Starting from $(R R / S S)-2 \mathrm{~F}$ (149 mg, $0.26 \mathrm{mmol})$, derivative $(R R / S S)-4 \mathrm{~F}(132 \mathrm{mg}, 80 \%)$ was prepared according to the same procedure used for the preparation of $(R S / S R)-4 \mathrm{~F} .{ }^{31} \mathrm{P}-\mathrm{NMR}\left(162 \mathrm{MHz}, \mathrm{CDCl}_{3}\right)$ : $\delta$ 26.25. ${ }^{1} \mathrm{H}-\mathrm{NMR}\left(300 \mathrm{MHz}, \mathrm{CDCl}_{3}\right): \delta 8.67(\mathrm{~d}, J=4.5 \mathrm{~Hz}, 2 \mathrm{H}) ; 8.54(\mathrm{~d}, J=7.9 \mathrm{~Hz}, 2 \mathrm{H}) ; 8.50(\mathrm{~s}, 2 \mathrm{H}) ; 7.79$ $(\mathrm{t}, J=7.7 \mathrm{~Hz}, 2 \mathrm{H}) ; 7.29-7.23(\mathrm{~m}, 2 \mathrm{H}) ; 5.65(\mathrm{q}, J=6.7 \mathrm{~Hz}, 1 \mathrm{H}) ; 4.60-4.44(\mathrm{~m}, 2 \mathrm{H}) ; 4.27-4.09(\mathrm{~m}, 2 \mathrm{H}) ; 3.47$ $(\mathrm{d}, J=24.8 \mathrm{~Hz}, 1 \mathrm{H}) ; 1.82(\mathrm{~d}, J=6.7 \mathrm{~Hz}, 3 \mathrm{H}) ; 1.58(\mathrm{t}, J=7.0 \mathrm{~Hz}, 3 \mathrm{H}) ; 1.55(\mathrm{~s}, 3 \mathrm{H}) ; 1.42(\mathrm{t}, J=7.1 \mathrm{~Hz}$, 3H); 1.37-1.32 (m, 12H). ${ }^{13} \mathrm{C}-\mathrm{NMR}\left(75 \mathrm{MHz}, \mathrm{CDCl}_{3}\right): \delta 176.6,155.9,155.8,154.8,148.8,136.9,123.6$, 121.5, 119.0, 84.6, 69.4, $68.7(\mathrm{~d}, J=139.7 \mathrm{~Hz}), 62.3(\mathrm{~d}, J=6.5 \mathrm{~Hz}), 59.8(\mathrm{~d}, J=7.5 \mathrm{~Hz}), 35.9(\mathrm{~d}, J=5.8 \mathrm{~Hz})$, $29.7(\mathrm{~d}, J=5.7 \mathrm{~Hz}), 27.2,25.0,21.1,16.7(\mathrm{~d}, J=5.6 \mathrm{~Hz}), 16.3(\mathrm{~d}, J=6.5 \mathrm{~Hz})$. HRMS (ESI) calculated for $\mathrm{C}_{30} \mathrm{H}_{42} \mathrm{~N}_{4} \mathrm{O}_{6} \mathrm{P}^{+}: 585.2837[\mathrm{M}+\mathrm{H}]^{+}$; found: 585.2838 .

1-(1-([2,2':6', 2' of $\mathrm{CuBr}(0.21 \mathrm{~g}, 1.47 \mathrm{mmol}, 1.0 \mathrm{eq}$.) and $\mathrm{Cu}(0.19 \mathrm{~g}, 2.94 \mathrm{mmol}, 2.0 \mathrm{eq}$.$) in degassed benzene (10 \mathrm{~mL})$ was added $N, N, N^{\prime}, N^{\prime \prime}, N^{\prime \prime}$-pentamethyldiethylenetriamine $(0.3 \mathrm{~mL}, 1.47 \mathrm{mmol}, 1.0$ eq.). The resulting mixture was stirred under argon atmosphere at room temperature for $10 \mathrm{~min}$, then a solution of the bromide compound $18(0.50 \mathrm{~g}, 1.47 \mathrm{mmol})$ and 4-Hydroxy-TEMPO (0.30 g, $1.76 \mathrm{mmol}, 1.2 \mathrm{eq}$. in degassed benzene $(10 \mathrm{~mL})$ was slowly added. The mixture was stirred overnight under argon atmosphere $(15 \mathrm{~h})$. The reaction mixture was then diluted with DCM, quenched and washed several times with saturated aqueous ammonia solution, water and brine. After drying with $\mathrm{MgSO}_{4}$, filtration and concentration, the crude product was chromatographed on silica gel deactivated by $10 \%$ TEA using a 40/60: petroleum ether/diethyl ether mixture as the eluting solvent to give $(R / S)-8 \mathrm{~F}$ as a white solid (0.43 g, 68\%). ${ }^{1} \mathrm{H}-\mathrm{NMR}\left(300 \mathrm{MHz}, \mathrm{CDCl}_{3}\right): \delta 8.71$ (ddd, $\left.J=4.8,1.7,0.8 \mathrm{~Hz}, 2 \mathrm{H}\right) ; 8.63(\mathrm{~d}, J=8.0 \mathrm{~Hz}$, $2 \mathrm{H}) ; 8.42(\mathrm{~s}, 2 \mathrm{H}) ; 7.84(\mathrm{td}, J=7.8,1.8 \mathrm{~Hz}, 2 \mathrm{H}) ; 7.32(\mathrm{ddd}, J=7.5,4.8,1.1 \mathrm{~Hz}, 2 \mathrm{H}) ; 4.98(\mathrm{q}, J=6.7 \mathrm{~Hz}$, $1 \mathrm{H}) ; 3.97-3.89(\mathrm{~m}, 1 \mathrm{H}) ; 1.84(\mathrm{dt}, J=12.3,3.6 \mathrm{~Hz}, 1 \mathrm{H}) ; 1.68(\mathrm{dt}, J=12.4,3.9 \mathrm{~Hz}, 1 \mathrm{H}) ; 1.59(\mathrm{~d}, J=6.7 \mathrm{~Hz}$, $3 \mathrm{H}) ; 1.53-1.45(\mathrm{~m}, 2 \mathrm{H}) ; 1.36(\mathrm{~s}, 3 \mathrm{H}) ; 1.26(\mathrm{~s}, 3 \mathrm{H}) ; 1.12(\mathrm{~s}, 3 \mathrm{H}) ; 0.76(\mathrm{~s}, 3 \mathrm{H}) .{ }^{13} \mathrm{C}-\mathrm{NMR}\left(75 \mathrm{MHz}, \mathrm{CDCl}_{3}\right)$ : $\delta 156.4 ; 156.3 ; 155.4 ; 149.1 ; 136.8 ; 123.7 ; 121.3 ; 118.9 ; 83.1 ; 63.2 ; 60.3 ; 60.1 ; 48.8 ; 34.6 ; 34.5 ; 30.3 ; 23.3 ; 21.4$. HRMS (ESI) calculated for $\mathrm{C}_{26} \mathrm{H}_{33} \mathrm{~N}_{4} \mathrm{O}_{2}{ }^{+}: 433.2598[\mathrm{M}+\mathrm{H}]^{+}$; found: 433.2593 .

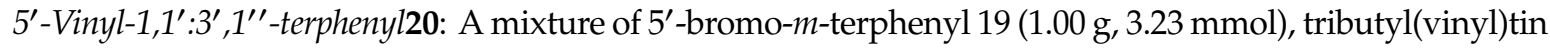
(1.23 mL, $4.2 \mathrm{mmol}, 1.3 \mathrm{eq}$.$) , TEA (1.23 mL, 9.7 \mathrm{mmol}, 3.0 \mathrm{eq}$.$) , and bis(triphenylphosphine)palladium$ dichloride $\left(0.11 \mathrm{~g}, 0.16 \mathrm{mmol}, 0.05 \mathrm{eq}\right.$.) in DMF $(20 \mathrm{~mL})$ was stirred at $90^{\circ} \mathrm{C}$ for $12 \mathrm{~h}$ under argon. The reaction mixture was then diluted with ice water $(100 \mathrm{~mL})$, stirred for $1 \mathrm{~h}$ and then extracted by ethyl acetate. The combined organic layers were washed with water, dried by $\mathrm{MgSO}_{4}$ and concentrated under reduced pressure. The crude product was chromatographed on silica gel using a $5 \%$ ethyl acetate in petroleum ether as the eluting solvent. Removal of the solvent under reduced pressure yielded vinyl derivative 20 as a white solid $(670 \mathrm{mg}, 80 \%) .{ }^{1} \mathrm{H}-\mathrm{NMR}\left(300 \mathrm{MHz}, \mathrm{CDCl}_{3}\right): \delta 7.74-7.59(\mathrm{~m}$, 7H); 7.52-7.44 (m, 4H); 7.43-7.35 (m, 2H); $6.87(\mathrm{dd}, J=17.6,10.9 \mathrm{~Hz}, 1 \mathrm{H}) ; 5.90(\mathrm{~d}, J=17.6 \mathrm{~Hz}, 1 \mathrm{H}) ; 5.36$ $(\mathrm{d}, J=10.9 \mathrm{~Hz}, 1 \mathrm{H}) .{ }^{13} \mathrm{C}-\mathrm{NMR}\left(75 \mathrm{MHz}, \mathrm{CDCl}_{3}\right): \delta 142.14 ; 141.11 ; 138.53 ; 136.79 ; 128.82 ; 127.52 ; 127.31$; 125.80; 124.13; 114.59. HRMS (ESI) calculated for $\mathrm{C}_{20} \mathrm{H}_{26} \mathrm{Ag}^{+}$: $363.0297[\mathrm{M}+\mathrm{Ag}]^{+}$; found: 363.0298 .

Diethyl(1-((1-([1,1':3',1'-terphenyl]-5'-yl)ethoxy)(1-((tert-butyldimethylsilyl)oxy)-2-methylpropan-2-yl)amino)2,2-dimethylpropyl)phosphonate (RR/SS)-6G and (RS/SR)-6G: To a stirred solution of Salen ligand 
( $63 \mathrm{mg}, 0.23 \mathrm{mmol}, 0.1$ eq. mol) in $\mathrm{EtOH}(10 \mathrm{~mL})$ was added $\mathrm{MnCl}_{2} \cdot 4 \mathrm{H}_{2} \mathrm{O}$ ( $46 \mathrm{mg}, 0.23 \mathrm{mmol}, 0.1$ eq.) in an opened flask. After $30 \mathrm{~min}$ of stirring at room temperature, a solution of SG1-OTBS (2.00 g, $4.68 \mathrm{mmol}, 2.0 \mathrm{eq}$.) and $5^{\prime}$-vinyl-1,1': $3^{\prime}, 1^{\prime \prime}$-terphenyl 20 (0.60 g, $\left.2.34 \mathrm{mmol}\right)$ in EtOH ( $\left.20 \mathrm{~mL}\right)$ was added, followed by solid $\mathrm{NaBH}_{4}(0.18 \mathrm{~g}$, $4.68 \mathrm{mmol}, 2.0 \mathrm{eq}$.) added in small portions. The resulting suspension was stirred at room temperature overnight $(15 \mathrm{~h})$. After checking the reaction for completion by TLC ( 0.5 eq. of $\mathrm{NaBH}_{4}$ can be added in case it does not reach completion), EtOH was removed and ice water was added. The reaction mixture was then DCM-extracted 3 times. The layers were separated, and the organic phase was washed with water, brine and dried with $\mathrm{MgSO}_{4}$. After concentration under reduced pressure, the residue was purified by column chromatography with $10 \%$ ethyl acetate in petroleum ether as the eluting solvent to afford $1.12 \mathrm{~g}$ of 2 diastereoisomer as a colorless oil: $0.78 \mathrm{~g}$ of (RS/SR)-6G and $0.34 \mathrm{~g}$ of the (RR/SS)-6G. (RS/SR)-6G: ${ }^{31} \mathrm{P}-\mathrm{NMR}\left(162 \mathrm{MHz}, \mathrm{CDCl}_{3}\right): \delta 24.99 .{ }^{1} \mathrm{H}-\mathrm{NMR}$ $\left(300 \mathrm{MHz}, \mathrm{CDCl}_{3}\right): \delta 7.71-7.66(\mathrm{~m}, 7 \mathrm{H}) ; 7.48-7.43(\mathrm{~m}, 4 \mathrm{H}) ; 7.38-7.34(\mathrm{~m}, 2 \mathrm{H}) ; 5.42(\mathrm{q}, J=6.4 \mathrm{~Hz}, 1 \mathrm{H})$; $4.04-3.86(\mathrm{~m}, 2 \mathrm{H}) ; 3.80(\mathrm{~d}, J=26.2 \mathrm{~Hz}, 1 \mathrm{H}) ; 3.73-3.32(\mathrm{~m}, 4 \mathrm{H}) ; 1.66(\mathrm{~d}, J=6.5 \mathrm{~Hz}, 3 \mathrm{H}) ; 1.26(\mathrm{~s}, 9 \mathrm{H})$; 1.24-1.21 (m, 9H); 0.94-0.91 (m, 12H); $0.07(\mathrm{~s}, 6 \mathrm{H}) .{ }^{13} \mathrm{C}-\mathrm{NMR}\left(75 \mathrm{MHz}, \mathrm{CDCl}_{3}\right): \delta 144.4 ; 141.4 ; 141.3$; $128.8 ; 127.3 ; 127.3 ; 125.6 ; 125.2 ; 78.5 ; 70.1(\mathrm{~d}, J=139.0 \mathrm{~Hz}) ; 69.1 ; 65.3 ; 61.8(\mathrm{~d}, J=6.5 \mathrm{~Hz}) ; 58.8(\mathrm{~d}$, $J=7.6 \mathrm{~Hz}) ; 35.5(\mathrm{~d}, J=5.3 \mathrm{~Hz}) ; 30.5(\mathrm{~d}, J=6.0 \mathrm{~Hz}) ; 25.9 ; 23.6 ; 22.6 ; 21.3 ; 18.3 ; 16.4(\mathrm{~d}, J=5.6 \mathrm{~Hz}) ; 16.2$ $(\mathrm{d}, J=7.1 \mathrm{~Hz}) ;-5.3 ;-5.4$. HRMS (ESI) calculated for $\mathrm{C}_{39} \mathrm{H}_{61} \mathrm{NO}_{5} \mathrm{PSi}^{+}: 682.4051[\mathrm{M}+\mathrm{H}]^{+}$; found: 682.4050. (RR/SS)-6G: ${ }^{31} \mathrm{P}-\mathrm{NMR}\left(162 \mathrm{MHz}, \mathrm{CDCl}_{3}\right): \delta 26.15 .{ }^{1} \mathrm{H}-\mathrm{NMR}\left(300 \mathrm{MHz}, \mathrm{CDCl}_{3}\right): \delta 7.70-7.64$ $(\mathrm{m}, 5 \mathrm{H}) ; 7.51-7.44(\mathrm{~m}, 6 \mathrm{H}) ; 7.40-7.35(\mathrm{~m}, 2 \mathrm{H}) ; 5.12(\mathrm{q}, J=6.5 \mathrm{~Hz}, 1 \mathrm{H}) ; 4.48-4.36(\mathrm{~m}, 1 \mathrm{H}) ; 4.28-3.95(\mathrm{~m}$, $3 \mathrm{H}) ; 3.76(\mathrm{~d}, J=26.4 \mathrm{~Hz}, 1 \mathrm{H}) ; 3.21$ (br.s, $2 \mathrm{H}) ; 1.69(\mathrm{~d}, J=6.7 \mathrm{~Hz}, 1 \mathrm{H}) ; 1.37(\mathrm{t}, J=7.0 \mathrm{~Hz}, 3 \mathrm{H}) ; 1.32(\mathrm{t}$, $J=7.1 \mathrm{~Hz}, 3 \mathrm{H}) ; 1.28(\mathrm{~s}, 9 \mathrm{H}) ; 0.98(\mathrm{~s}, 3 \mathrm{H}) ; 0.97(\mathrm{~s}, 3 \mathrm{H}) ; 0.78(\mathrm{~s}, 9 \mathrm{H}) ;-0.23(\mathrm{~s}, 3 \mathrm{H}) ;-0.24(\mathrm{~s}, 3 \mathrm{H}) .{ }^{13} \mathrm{C}-\mathrm{NMR}$ (75 MHz, $\left.\mathrm{CDCl}_{3}\right): \delta 146.9 ; 141.7 ; 141.2 ; 128.8 ; 127.4 ; 127.2 ; 124.9 ; 124.5 ; 86.0 ; 69.8 ; 69.8$ (d, J = $\left.138.5 \mathrm{~Hz}\right)$; $65.5 ; 61.8(\mathrm{~d}, J=6.3 \mathrm{~Hz}) ; 58.9(\mathrm{~d}, J=7.0 \mathrm{~Hz}) ; 35.8(\mathrm{~d}, J=6.1 \mathrm{~Hz}) ; 30.0(\mathrm{~d}, J=5.8 \mathrm{~Hz}) ; 25.8 ; 25.1 ; 23.8 ; 22.3$; $18.0 ; 16.8(\mathrm{~d}, J=5.6 \mathrm{~Hz}) ; 16.3(\mathrm{~d}, J=6.8 \mathrm{~Hz}) ;-5.6 ;-5.7$. HRMS (ESI) calculated for $\mathrm{C}_{39} \mathrm{H}_{61} \mathrm{NO}_{5} \mathrm{PSi}^{+}$: $682.4051[\mathrm{M}+\mathrm{H}]^{+}$; found: 682.4047 .

Diethyl(1-((1-([1,1':3',1'-terphenyl]-5'-yl)ethoxy)(1-hydroxy-2-methylpropan-2-yl)amino)-2,2-dimethylpropyl) phosphonate (RS/SR)-2G: To a solution of compound (RS/SR)-6G $(0.50 \mathrm{~g}, 0.73 \mathrm{mmol})$ in dry THF $(10 \mathrm{~mL})$ was added $\mathrm{HF} / \mathrm{Py}(0.5 \mathrm{~mL})$ at $0{ }^{\circ} \mathrm{C}$, and the mixture was stirred at room temperature for $12 \mathrm{~h}$. The reaction was quenched by the addition of a saturated solution of $\mathrm{NaHCO}_{3}(20 \mathrm{~mL})$ to $\mathrm{pH} 8$, extracted with DCM and washed with water, $1 \mathrm{M} \mathrm{HCl}$ solution and brine. The combined organic phase was dried with $\mathrm{MgSO}_{4}$ and then concentrated under reduced pressure. The crude product was chromatographed on silica gel using a 30\% ethyl acetate in petroleum ether mixture as the eluting solvent. Removal of the solvent under reduced pressure yielded compound (RS/SR)-2G as a white solid (0.35 g, 85\%). (RS/SR)-2G: ${ }^{31} \mathrm{P}-\mathrm{NMR}\left(162 \mathrm{MHz}, \mathrm{CDCl}_{3}\right): \delta 26.99 .{ }^{1} \mathrm{H}-\mathrm{NMR}(300 \mathrm{MHz}$, $\left.\mathrm{CDCl}_{3}\right): \delta 7.69-7.64(\mathrm{~m}, 7 \mathrm{H}) ; 7.48-7.43(\mathrm{~m}, 4 \mathrm{H}) ; 7.38-7.33(\mathrm{~m}, 2 \mathrm{H}) ; 5.25(\mathrm{q}, J=6.4 \mathrm{~Hz}, 1 \mathrm{H}) ; 4.07-3.79(\mathrm{~m}$, $5 \mathrm{H}) ; 3.68-3.54(\mathrm{~m}, 2 \mathrm{H}) ; 1.65(\mathrm{~d}, J=6.5 \mathrm{~Hz}, 3 \mathrm{H}) ; 1.33(\mathrm{~s}, 3 \mathrm{H}) ; 1.23-1.15(\mathrm{~m}, 15 \mathrm{H}) ; 1.01(\mathrm{t}, J=7.0 \mathrm{~Hz}$, $3 \mathrm{H}) .{ }^{13} \mathrm{C}-\mathrm{NMR}\left(75 \mathrm{MHz}, \mathrm{CDCl}_{3}\right): \delta 144.8 ; 141.5 ; 141.2 ; 128.8 ; 127.4 ; 127.2 ; 124.8 ; 124.2 ; 78.3 ; 69.7(\mathrm{~d}$, $J=135.7 \mathrm{~Hz}) ; 67.8 ; 64.8 ; 62.1(\mathrm{~d}, J=6.5 \mathrm{~Hz}) ; 60.8(\mathrm{~d}, J=7.9 \mathrm{~Hz}) ; 35.4(\mathrm{~d}, J=3.9 \mathrm{~Hz}) ; 30.7(\mathrm{~d}, J=5.6 \mathrm{~Hz})$; 26.5; 24.6; $22.3 ; 16.7(\mathrm{~d}, J=5.6 \mathrm{~Hz}) ; 15.9(\mathrm{~d}, J=6.7 \mathrm{~Hz})$. HRMS (ESI) calculated for $\mathrm{C}_{33} \mathrm{H}_{47} \mathrm{NO}_{5} \mathrm{P}^{+}$: $568.3186[\mathrm{M}+\mathrm{H}]^{+}$; found: 568.3186 .

Starting from $(R R / S S)-6 \mathrm{G}(0,51 \mathrm{~g}, 0.25 \mathrm{mmol})$, derivative $(R R / S S)-2 \mathrm{G}(366 \mathrm{mg}, 85 \%)$ was prepared according to the same procedure used in the preparation of (RS/SR)-2G. ${ }^{31} \mathrm{P}-\mathrm{NMR}\left(162 \mathrm{MHz}, \mathrm{CDCl}_{3}\right)$ : $\delta$ 27.16. ${ }^{1} \mathrm{H}-\mathrm{NMR}\left(300 \mathrm{MHz}, \mathrm{CDCl}_{3}\right): \delta 7.72-7.63(\mathrm{~m}, 5 \mathrm{H}) ; 7.55(\mathrm{~s}, 2 \mathrm{H}) ; 7.49-7.44(\mathrm{~m}, 4 \mathrm{H}) ; 7.39-7.34(\mathrm{~m}$, $2 \mathrm{H}) ; 5.09(\mathrm{q}, J=6.4 \mathrm{~Hz}, 1 \mathrm{H}) ; 4.36-4.08(\mathrm{~m}, 5 \mathrm{H}) ; 3.70(\mathrm{~d}, J=26.1 \mathrm{~Hz}, 1 \mathrm{H}) ; 3.64(\mathrm{~d}, J=9.4 \mathrm{~Hz}, 1 \mathrm{H}) ; 3.16(\mathrm{~d}$, $J=12.1 \mathrm{~Hz}, 1 \mathrm{H}) ; 1.64(\mathrm{~d}, J=6.6 \mathrm{~Hz}, 3 \mathrm{H}) ; 1.37(\mathrm{t}, J=7.1 \mathrm{~Hz}, 6 \mathrm{H}) ; 1.25(\mathrm{~s}, 9 \mathrm{H}) ; 1.08(\mathrm{~s}, 3 \mathrm{H}) ; 0.83$ (br.s, 3H). ${ }^{13} \mathrm{C}-\mathrm{NMR}\left(75 \mathrm{MHz}, \mathrm{CDCl}_{3}\right): \delta 146.1 ; 141.7 ; 141.1 ; 128.8 ; 127.4 ; 127.3 ; 125.1 ; 124.6 ; 85.3 ; 69.5(\mathrm{~d}$, $J=135.8 \mathrm{~Hz}) ; 67.3 ; 65.0 ; 61.9(\mathrm{~d}, J=6.5 \mathrm{~Hz}) ; 60.5(\mathrm{~d}, J=7.7 \mathrm{~Hz}) ; 35.7(\mathrm{~d}, J=4.6 \mathrm{~Hz}) ; 30.2(\mathrm{~d}, J=5.2 \mathrm{~Hz}) ;$ $27.1 ; 24.4 ; 23.7 ; 16.6(\mathrm{~d}, J=5.7 \mathrm{~Hz}) ; 16.3(\mathrm{~d}, J=6.6 \mathrm{~Hz})$. HRMS (ESI) calculated for $\mathrm{C}_{33} \mathrm{H}_{47} \mathrm{NO}_{5} \mathrm{P}^{+}$: $568.3186[\mathrm{M}+\mathrm{H}]^{+}$; found: 568.3184 . 


\subsection{Evaluation against P. falciparum}

\subsubsection{Parasite Culture}

F32-ART5, an artemisinin-resistant strain and F32-TEM, an artemisinin-sensitive strain, were obtained from the parental clone F32-Tanzania, respectively under regular drug pressure cycles of increasing artemisinin concentrations for 5 years and without any artemisinin pressure [42]. After these drug pressure cycles allowing selection of the F32-ART5 strain, regular drug pressures were performed to maintain its phenotype. ART-resistant and ART-sensitive strains, as well as the chloroquine-resistant FcB1-Columbia strain were cultured according to the Trager and Jensen protocol with modifications [43]. Briefly, parasites were cultured in RPMI 1640 (Fisher Scientific, Waltham, Illkirch-Graffenstaden, France) supplemented with 5\% type AB human serum (Etablissement français du Sang, Toulouse, France) and adjusted at a parasitemia of $1 \%$ and $2 \%$ hematocrit with type $\mathrm{O}$ human at $37^{\circ} \mathrm{C}$ and $5 \% \mathrm{CO}_{2}$. Parasite development was daily monitored by Giemsa staining.

\subsubsection{In Vitro Antimalarial Activities}

The antiplasmodial activities of alkoxyamines were first evaluated on the chloroquine-resistant FcB1-Columbia strain at the dose of $10 \mu \mathrm{M}$, in triplicate and on 2 independent experiments using the SYBR Green I method [44]. Results are reported in Table S1. Drugs inducing around or more than 50\% parasite growth inhibition at $10 \mu \mathrm{M}$ were then also tested at least twice in a standard chemosensitivity assay to determine their exact $\mathrm{IC}_{50}$ values (values in bold-face type in Table S1, Supporting Information). The molecules with the best $\mathrm{IC}_{50}$ values (a total of 18) were then also evaluated on both F32-ART5 and F32-TEM strains (Table 1). Artemisinin (TCI Europe N.V., Eschborn, Germany) and chloroquine (Sigma-Aldrich, Saint-Quentin-Fallavier, France) were used as antimalarial reference compounds. Briefly, for the determination of $\mathrm{IC}_{50}$ values, the chemosensitivity assay was carried out in 96-well culture plates on D-sorbitol ring-stage synchronized parasites [45] and antiplasmodial activities were evaluated using the SYBR Green I method [44]. Drug testing was performed in triplicates in a dose range of 5 to 7 concentrations. All the compounds were received as powders and dissolved in DMSO to a stock solution of $10 \mathrm{mg} / \mathrm{mL}$, except for chloroquine dissolved in RPMI 1640. Serial dilutions were carried out in RPMI 1640 to yield a final DMSO concentration of $1 \%$ in the well, a concentration that was verified as not affecting parasite growth. Parasites were left to proliferate with the given compounds for $48 \mathrm{~h}$ at $37^{\circ} \mathrm{C}$ and $5 \% \mathrm{CO}_{2}$. After this period, pellets were washed 3 times in sterile PBS prior to putting the plates at $-20^{\circ} \mathrm{C}$ overnight to lyse all red blood cells. The following day, the plates were thawed at room temperature, $100 \mu \mathrm{L}$ of each well was transferred into a black 96-well plate to which another $100 \mu \mathrm{L}$ of $2 \times$ PBS-diluted SYBR Green I (Sigma-Aldrich) was added and left to incubate for $2 \mathrm{~h}$ at room temperature prior to reading the plates on BioTek FL $\times 800$ Microplate Fluorescence Reader $\left(\lambda_{\text {excitation }}=485 \mathrm{~nm}, \lambda_{\text {emission }}=528 \mathrm{~nm}\right)$. Control parasite culture (i.e., RPMI with 1\% DMSO) was referred to as $100 \%$ growth, and the percentage of growth inhibition was determined as follows:

$$
\% \text { inhibition }=100-100 \times \frac{\text { Signal }(\text { molecule })-\text { Signal }(\text { background noise })}{\text { Signal }(\text { DMSO })-\text { Signal }(\text { background noise })}
$$

$\mathrm{IC}_{50}$ values were determined using GraphPad Prism by drawing the curve \% inhibition vs. [Drug] and using a four-parameter dose-response curve with the following equation:

$$
Y=\text { Bottom }+\frac{\text { Top }- \text { Bottom }}{1+\frac{x^{\text {Hill Slope }}}{I C_{50}^{\text {Hill Slope }}}}
$$

\subsubsection{Recrudescence Assay}

The lead compound, (RS/SR)-2F, was tested in a recrudescence assay, to assess cross-resistance with artemisinin, according to Ménard et al. [5]. Briefly, F32-TEM and F32-ART5 parasites were 
synchronized at ring-stage by D-sorbitol treatment prior to treating them with the drug of interest for $48 \mathrm{~h}$, then washed and allowed to grow in drug-free medium. Parasitemia was monitored every other day for 30 days to determine the day when parasite cultures reached the $t_{0}$ initial parasitemia. The drug concentration of $5 \mu \mathrm{M}$ tested for (RS/SR)-2F was determined with preliminary tests and 10-fold of the $\mathrm{IC}_{50}$ was retained. Artemisinin was used as control to confirm differences in recrudescence times between both strains [42]. Three independent experiments were performed for (RS/SR)-2F and artemisinin tested in parallel. Results are displayed in Table 2.

\subsection{Evaluation against S. mansoni}

\subsubsection{Parasite Culture}

The NMRI strain of Schistosoma mansoni was used for the experimentations. The parasite was maintained on an albino variety of Biomphalaria glabrata from Brazil (intermediate host) and in Golden Hamsters, Mesocricetus auratus (Janvier Labs, Le Genest-Saint-Isle, France). Detailed methods, for mollusk and hamster infections and for parasite recovery, were previously described [46].

\subsubsection{In Vitro Antischistosomal Activities}

Adult worms were recovered between 42 and 47 days after infection by hepatic perfusion technique. Twenty to fifty adult worms were disposed in 12-well Falcon ${ }^{\circledR}$ plate containing $2 \mathrm{~mL}$ of RPMI 1640 (supplemented with L-glutamine and Hepes $25 \mathrm{mM}$ ) and stored in an incubator chamber $\left(37^{\circ} \mathrm{C} ; 5 \% \mathrm{CO}_{2}\right)$. Drug preparation started with dissolution of the drug in DMSO to give a $100 \mathrm{mg} / \mathrm{mL}$ stock solution. The dilution was complemented with Tween 80 and RPMI in order to obtain the following final ratio dilution: RPMI 1640/Tween 80/DMSO, 1000/0.95/3.8, v/v/v. The drug solution was added to Falcon plates that contained adult worms. The S. mansoni cultures were then incubated with each drug at a final concentration of $100 \mu \mathrm{g} / \mathrm{mL}$. Positive control was carried out with a solution of praziquantel (Merck KGaA, Darmstadt, Germany) at a concentration of $100 \mu \mathrm{g} / \mathrm{mL}$. Negative control was carried out with the same RPMI 1640/Tween 80/DMSO solution, but without any drug. Each test was performed in duplicate. Every hour, moving worms were counted in order to define the percentage of survivors. Parasites showing no body contractions during a 30 s observation were considered as dead. Observations were extended to $8 \mathrm{~h}$. Mean survival times ( \pm standard deviation) were calculated for each drug using Kaplan-Meier survival analyses.

Housing, feeding and animal care followed the national ethical standards established in the writ of February 1st, 2013 (NOR: AGRG1238753A). The IHPE lab possesses the permit A66040 for the animal experiments and certificate for the experimenters (authorization 007083, decree 87-848).

\subsection{Cytotoxicity Assays}

Cytotoxicity of the compounds was evaluated against Vero cells, a non-cancerous mammalian line, with a similar dilution protocol as for antiplasmodial evaluations (the final DMSO concentration was $0.5 \%$ vol). Vero cells were cultured in MEM (Dutscher, Brumath, France) supplemented with $10 \%$ fetal bovine serum, $1 \times$ non-essential amino acids, $100 \mathrm{U} / \mathrm{mL}, 100 \mu \mathrm{g} / \mathrm{mL}$ penicillin/streptomycin, and $2 \mathrm{mM}$ L-glutamine at $37{ }^{\circ} \mathrm{C}$ in a humidified $5 \% \mathrm{CO}_{2}$ atmosphere [47]. Vero cells $(100 \mu \mathrm{L}$ of $10^{5}$ cells/mL per well) were plated in 96-well plates for $24 \mathrm{~h}$, before treating them with $100 \mu \mathrm{L}$ of drug dilutions. Vero cells were then left to incubate for $48 \mathrm{~h}$ with the drugs. At this time, each well was microscope-examined for detection of possible precipitate formation prior to remove the supernatant by flicking the plate. $100 \mu \mathrm{L}$ of a $0.5 \mathrm{mg} / \mathrm{mL}$ PBS-dissolved MTT tetrazolium (stock solution at $5 \mathrm{mg} / \mathrm{mL}$ ) was then added to each well [48]. The plates were then incubated for $1 \mathrm{~h}$ at $37^{\circ} \mathrm{C}$ and $5 \% \mathrm{CO}_{2}$ prior to removing the supernatant and adding $100 \mu \mathrm{L}$ of DMSO. Plates were gently shaken to dissolve formazan crystals resulting from the MTT tetrazolium reduction by living cells and read at $570 \mathrm{~nm}$ with BioTek $\mu$ Quant Microplate Spectrophotometer. IC $_{50}$ values were determined using GraphPad 
Prism, in a similar fashion to what was carried out on P. falciparum (\% inhibition vs. [Drug]) and the percentage of growth inhibition was determined as follows:

$$
\% \text { inhibition }=100-100 \times \frac{\text { Signal }(\text { molecule })}{\operatorname{Signal}(\text { DMSO })}
$$

Results are displayed in Table 1.

\subsection{Computational Studies}

The geometry of the structures was optimized at the B3LYP/3-21G* model chemistry with the GAUSSIAN 09 program [49]. The bulk solvent effects were described with the integral equation formalism polarizable continuum Model (IEFPCM) with water as solvent [50]. Vibrational frequencies were computed to confirm the convergence to local minima and to calculate the unscaled zero-point-energy (ZPE) and the Gibb's free energy at $298 \mathrm{~K}$.

\subsection{Reactivity of Alkoxyamines toward Heme}

\subsubsection{Materials and Analytical Conditions}

Hemin (Fe ${ }^{\mathrm{III}}(\mathrm{PPIX}) \mathrm{Cl}$ ) and other commercially available reagents (analytical grade) were purchased from usual suppliers, and used without further purification.

${ }^{1} \mathrm{H}$ and ${ }^{13} \mathrm{C}-\mathrm{NMR}$ spectra were recorded at $293 \mathrm{~K}$ on Bruker Avance 400 and Bruker Ascend 600 spectrometers. All chemical shifts for ${ }^{1} \mathrm{H}$ were relative to TMS using ${ }^{1} \mathrm{H}$ residual chemical shifts of the deuterated solvent as a secondary standard. Diffusion ordered spectroscopy (DOSY) NMR was used to measure the translational diffusion coefficient D. The DOSY spectra were acquired at $293 \mathrm{~K}$ with the stebpgp1s pulse program from Bruker topspin software. All spectra were recorded with $16 \mathrm{~K}$ time domain data points in the $\mathrm{t} 2$ dimension and $16 \mathrm{t} 1$ increments. The gradient strength was linearly incremented in 16 steps from $2 \%$ up to $95 \%$ of the maximum gradient strength. All measurements were performed with a compromise diffusion delay $\Delta$ of $160 \mathrm{~ms}$ and a gradient pulse length $\delta$ of $2.8 \mathrm{~ms}$. After cooling the reaction mixtures to room temperature, $0.5 \mathrm{~mL}$ of each mixture was withdrawn. To this aliquot, a solution of $\mathrm{KCN}$ in methanol- $d_{4}$ was added [ $320 \mathrm{mM}, 10 \mu \mathrm{L}, 3$ mole equivalent of $\mathrm{CN}^{-}$ with respect to $\mathrm{Fe}(\mathrm{III})]$. Final DMSO/methanol ratio $=98 / 2, v / v$.

LC-MS analyses were carried out on an LCQ Fleet ThermoFisher equipment, with a Waters X-Bridge C18 column ( $5 \mu \mathrm{m}$ or $3.5 \mu \mathrm{m}, 4.6 \times 100 \mathrm{~mm})$. The samples were prepared as follows: an aliquot $(5 \mu \mathrm{L})$ of the reaction mixture was diluted in DMSO $(1.0 \mathrm{~mL})$. For analysis of the reaction of 2F with heme, eluents were (A) water/methanol/formic acid, 40/60/1, $v / v / v$, and (B) methanol/formic acid, $100 / 1, v / v$. The gradient was the following: from $\mathrm{A} / \mathrm{B}=100 / 0$ to $\mathrm{A} / \mathrm{B}=20 / 80$ in $15 \mathrm{~min}$, then $\mathrm{A} / \mathrm{B}=20 / 80$ until $30 \mathrm{~min}$. Flow rate was $0.4 \mathrm{~mL} / \mathrm{min}$. UV-vis detection was at $254 \mathrm{~nm}$ and $406 \mathrm{~nm}$. For analysis of the reaction of $\mathbf{8 F}$ with heme, eluents were $(\mathrm{A})$ water/formic acid, 100/0.1, $v / v$ and (B) acetonitrile/formic acid, 100/0.1, v/v. The gradient was the following: from $\mathrm{A} / \mathrm{B}=65 / 35$ until $1 \mathrm{~min}$, then from $\mathrm{A} / \mathrm{B}=65 / 35$ to $\mathrm{A} / \mathrm{B}=30 / 70$ in $11 \mathrm{~min}$; $\mathrm{A} / \mathrm{B}$ was then kept at 30/70 for $1 \mathrm{~min}$, then increased to $5 / 95 \mathrm{in} 3 \mathrm{~min}$, and kept at 5/95 for $4 \mathrm{~min}$. Flow rate was $0.5 \mathrm{~mL} / \mathrm{min}$. UV-vis detection was at $260 \mathrm{~nm}$, $279 \mathrm{~nm}$ and $400 \mathrm{~nm}$.

\subsubsection{Reaction of $(R R / S S)-1$ a or $(R S / S R)$-1a with Fe(III)-heme}

In a schlenk tube flushed with $\left.\mathrm{Ar}, \mathrm{Fe} \mathrm{eII}^{\mathrm{II}} \mathrm{PPIX}\right) \mathrm{Cl}(4.9 \mathrm{mg})$ and $1 \mathrm{a}(3.0 \mathrm{mg})$ were added. Degassed DMSO was then added $(0.8 \mathrm{~mL}$, [heme $]=[\mathbf{1 a}]=9.4 \mathrm{mM})$, and the mixture was heated at $80{ }^{\circ} \mathrm{C}$ for $6 \mathrm{~h}$, under magnetic stirring. The reaction was monitored as follows: an aliquot $(5 \mu \mathrm{L})$ of the reaction mixture was then diluted in DMSO $(250 \mu \mathrm{L})$ for LC-MS analyses. $t_{R}$ [heme $)=9.6 \mathrm{~min}, \mathrm{~m} / z=616.6\left(\mathrm{M}^{+}\right)$; $t_{\mathrm{R}}[\mathbf{1 a}]=10.4 \mathrm{~min}, m / z=401.2\left(\mathrm{MH}^{+}\right) ; \mathrm{t}_{\mathrm{R}}\left[\left(\mathrm{R}_{1}, \mathrm{R}_{2}-\mathrm{NO}\right)=10.5 \mathrm{~min}, \mathrm{~m} / z=295.2\left(\mathrm{M}^{+}\right), 317.2\left(\mathrm{M}^{2} \mathrm{Na}^{+}\right)\right.$. 


\subsubsection{Reaction of $(R S / S R)-2 \mathrm{~F}$ and $(R R / S S)-2 \mathrm{~F}$ with $\mathrm{Fe}(\mathrm{III})$-heme}

For reactions carried out under air, $\mathrm{Fe} \mathrm{III}^{\mathrm{II}}$ (PPIX)Cl $(3.7 \mathrm{mg})$ and $2 \mathrm{~F}(3.3 \mathrm{mg})$ were heated at $95^{\circ} \mathrm{C}$ for $6 \mathrm{~h}$, in DMSO- $d_{6}(0.8 \mathrm{~mL})$ under magnetic stirring ([heme $\left.]=[2 \mathrm{~F}]=6.7 \mathrm{mM}\right)$. When the reaction was carried out under argon, the schlenk tube was flushed with $\mathrm{Ar}$ prior to the addition of $\mathrm{Fe}^{\mathrm{III}}$ (PPIX)Cl and 2F. Degassed DMSO- $d_{6}(0.8 \mathrm{~mL})$ was then added, and the mixture was heated at $95{ }^{\circ} \mathrm{C}$ for $6 \mathrm{~h}$, under magnetic stirring. After cooling the reaction mixture to room temperature, LC-MS and NMR analyses were carried out as described above. ${ }^{1} \mathrm{H}-\mathrm{NMR}$ for compound $22(600 \mathrm{MHz}): \delta, \mathrm{ppm}: 8.72(2 \mathrm{H}$, $\mathrm{H} 6$ and $\left.\mathrm{H}^{\prime \prime}{ }^{\prime}\right), 8.62\left(2 \mathrm{H}, \mathrm{H} 3\right.$ and $\left.\mathrm{H}^{\prime \prime}{ }^{\prime \prime}\right), 8.33\left(2 \mathrm{H}, \mathrm{H} 3^{\prime}\right.$ and $\left.\mathrm{H} 5^{\prime}\right), 8.00\left(2 \mathrm{H}, \mathrm{H} 4\right.$ and $\left.\mathrm{H} 4^{\prime \prime}\right), 7.50(2 \mathrm{H}, \mathrm{H} 5$ and $\left.\mathrm{H}^{\prime \prime}\right), 2.85\left(2 \mathrm{H}, \mathrm{C}^{\prime}-\mathrm{CH}_{2}\right), 1.30\left(3 \mathrm{H}, \mathrm{C}^{\prime}-\mathrm{CH}_{2}-\mathrm{CH}_{3}\right) .{ }^{13} \mathrm{C}-\mathrm{NMR}$ for compound 22 (151 MHz, partial data): $\delta$, ppm: $120.0\left(\mathrm{C}^{\prime}\right.$ and $\left.\mathrm{C}^{\prime}\right), 28.3\left(\mathrm{C}^{\prime}-\mathrm{CH}_{2}\right), 15.1\left(\mathrm{C}^{\prime}-\mathrm{CH}_{2}-\mathrm{CH}_{3}\right) .{ }^{1} \mathrm{H}-\mathrm{NMR}$ for compound 24 (600 MHz): $\delta$, ppm: $8.87\left(2 \mathrm{H}, \mathrm{H}^{\prime}{ }^{\prime}\right.$ and $\left.\mathrm{H}^{\prime}\right), 8.76\left(2 \mathrm{H}, \mathrm{H} 6\right.$ and $\left.\mathrm{H}^{\prime \prime}{ }^{\prime \prime}\right), 8.66\left(2 \mathrm{H}, \mathrm{H} 3\right.$ and $\left.\mathrm{H}^{\prime \prime}\right), 8.01$ $\left(2 \mathrm{H}, \mathrm{H} 4\right.$ and $\left.\mathrm{H}^{\prime \prime}{ }^{\prime \prime}\right), 7.50\left(2 \mathrm{H}, \mathrm{H} 5\right.$ and $\left.\mathrm{H}^{\prime \prime}{ }^{\prime \prime}\right), 2.72\left(3 \mathrm{H}, \mathrm{C} 4^{\prime}-\mathrm{CO}-\mathrm{CH}_{3}\right) .{ }^{13} \mathrm{C}-\mathrm{NMR}$ for compound 24 (151 MHz): $\delta$, ppm: $198.0(\mathrm{CO}), 156.2$ and $154.6\left(\mathrm{C} 2, \mathrm{C}^{\prime}, \mathrm{C}^{\prime}\right.$ and $\left.\mathrm{C}^{\prime \prime}{ }^{\prime}\right), 140.7$ (C6 and $\left.\mathrm{C}^{\prime \prime}{ }^{\prime \prime}\right), 137.7$ (C4 and $\left.\mathrm{C}^{\prime \prime}{ }^{\prime \prime}\right), 124.9\left(\mathrm{C} 5\right.$ and $\left.\mathrm{C}^{\prime \prime}{ }^{\prime \prime}\right), 121.2\left(\mathrm{C} 3\right.$ and $\left.\mathrm{C}^{\prime \prime}{ }^{\prime \prime}\right), 118.3\left(\mathrm{C}^{\prime}\right.$ and $\left.\mathrm{C}^{\prime}\right), 26.8\left(\mathrm{C}^{\prime}-\mathrm{CO}-\mathrm{CH}_{3}\right) .{ }^{1} \mathrm{H}-\mathrm{NMR}$ for compound 25 (600 MHz): $\delta$, ppm: $8.53\left(2 \mathrm{H}, \mathrm{H}^{\prime}\right.$ and $\left.\mathrm{H}^{\prime}\right), 8.72\left(2 \mathrm{H}, \mathrm{H} 6\right.$ and $\left.\mathrm{H}^{\prime \prime}\right), 8.64(2 \mathrm{H}, \mathrm{H} 3$ and $\left.\mathrm{H}^{\prime \prime}{ }^{\prime \prime}\right), 7.97\left(2 \mathrm{H}, \mathrm{H} 4\right.$ and $\left.\mathrm{H} 4^{\prime \prime}\right), 7.44\left(2 \mathrm{H}, \mathrm{H} 5\right.$ and $\left.\mathrm{H}^{\prime \prime}{ }^{\prime \prime}\right), 4.97\left(1 \mathrm{H}, \mathrm{C} 4^{\prime}-\mathrm{CH}(\mathrm{OH})-\mathrm{CH}_{3}\right), 1.45(3 \mathrm{H}$, $\left.\mathrm{C}^{\prime}-\mathrm{CH}(\mathrm{OH})-\mathrm{CH}_{3}\right) .{ }^{13} \mathrm{C}-\mathrm{NMR}$ for compound 25 (151 MHz): $\delta$, ppm: 155.6 and $154.9\left(\mathrm{C} 2, \mathrm{C}^{\prime}, \mathrm{C}^{\prime}\right.$ and $\left.\mathrm{C} 2^{\prime \prime}\right), 149.2$ (C6 and $\left.\mathrm{C}^{\prime \prime}{ }^{\prime}\right), 137.4\left(\mathrm{C} 4\right.$ and $\left.\mathrm{C}^{\prime \prime}{ }^{\prime}\right), 124.3$ (C5 and $\left.\mathrm{C}^{\prime \prime}{ }^{\prime \prime}\right), 121.0$ (C3 and $\left.\mathrm{C} 3^{\prime \prime}\right), 117.7\left(\mathrm{C} 3^{\prime}\right.$ and $\left.\mathrm{C}^{\prime}\right), 68.0\left(\mathrm{C} 4^{\prime}-\mathrm{CH}(\mathrm{OH})-\mathrm{CH}_{3}\right), 25.4\left(\mathrm{C} 4^{\prime}-\mathrm{CH}(\mathrm{OH})-\mathrm{CH}_{3}\right)$.

LC-MS: $\mathrm{t}_{\mathrm{R}}[(R R / S S)-2 \mathrm{~F}$ or $(R S / S R)-2 \mathrm{~F}]=13.4 \mathrm{~min}, \mathrm{~m} / \mathrm{z}=571.3\left(\mathrm{M}+\mathrm{H}^{+}\right) ; \mathrm{t}_{\mathrm{R}}[22]=4.7 \mathrm{~min}$, $m / z=262.3\left(\mathrm{M}+\mathrm{H}^{+}\right), 284.3\left(\mathrm{M}+\mathrm{Na}^{+}\right) ; \mathrm{t}_{\mathrm{R}}[24]=8.0$ and $10.0 \mathrm{~min}, \mathrm{~m} / \mathrm{z}=521.4\left(\mathrm{M}+\mathrm{H}^{+}\right), 543.4(\mathrm{M}+$ $\left.\mathrm{Na}^{+}\right) ; \mathrm{t}_{\mathrm{R}}[25]=5.8 \mathrm{~min}, \mathrm{~m} / \mathrm{z}=276.3\left(\mathrm{M}+\mathrm{H}^{+}\right), 298.3\left(\mathrm{M}+\mathrm{Na}^{+}\right)$.

\subsubsection{Reaction of $(R / S)-8 \mathrm{~F}$ with $\mathrm{Fe}(\mathrm{III})$-heme}

$\mathrm{Fe}^{\mathrm{III}}$ (PPIX)Cl (40 $\mu \mathrm{L}$ of a solution containing $4.1 \mathrm{mg}$ of $\mathrm{Fe}{ }^{\mathrm{III}}$ (PPIX)Cl in $250 \mu \mathrm{L}$ of DMSO- $d_{6}$, $1.0 \mu \mathrm{mol})$ and $\mathbf{8 F}\left(10 \mu \mathrm{L}\right.$ of a solution containing $16.7 \mathrm{mg}$ of $\mathbf{8 F}$ in $400 \mu \mathrm{L}$ of DMSO- $\left.d_{6}, 0.97 \mu \mathrm{mol}\right)$ were added in a round-bottom flask containing $450 \mu \mathrm{L}$ of DMSO- $d_{6}$. The solution was then heated at $100{ }^{\circ} \mathrm{C}$ for $3 \mathrm{~h}$ under air, with magnetic stirring ([heme] $=[8 \mathrm{~F}]=1.9-2.0 \mathrm{mM}$ ). After cooling the reaction mixture to room temperature, LC-MS and NMR analyses were carried out as described above. ${ }^{1} \mathrm{H}-\mathrm{NMR}$ for compound $\mathbf{2 4}$ and $\mathbf{2 4 -} \boldsymbol{d}$ ( $82 \%$ with respect to the terpyridine fragment) (600 MHz): $\delta$, ppm: $8.83\left(2 \mathrm{H}, \mathrm{H} 3^{\prime}\right.$ and $\left.\mathrm{H}^{\prime}\right), 8.77\left(2 \mathrm{H}, \mathrm{H} 6\right.$ and $\left.\mathrm{H}^{\prime \prime}\right), 8.67\left(2 \mathrm{H}, \mathrm{H} 3\right.$ and $\left.\mathrm{H} 3^{\prime \prime}\right), 8.06\left(2 \mathrm{H}, \mathrm{H} 4\right.$ and $\left.\mathrm{H} 4^{\prime \prime}\right), 7.56$ $\left(2 \mathrm{H}, \mathrm{H} 5\right.$ and $\left.\mathrm{H}^{\prime \prime}{ }^{\prime}\right), 2.78\left(\mathrm{~s}, 1.35 \mathrm{H}=3 \mathrm{H} \times 45 \mathrm{~mol} \%\right.$ of $\left.24, \mathrm{C}^{\prime}-\mathrm{CO}-\mathrm{CH}_{3}\right), 2.76\left(\mathrm{tr}^{2}{ }^{2} \mathrm{~J}_{\mathrm{HD}}=1.8 \mathrm{~Hz}, 1.1 \mathrm{H}=2 \mathrm{H}\right.$ $\times 55 \mathrm{~mol} \%$ of $\left.24-d, \mathrm{C}^{\prime}-\mathrm{CO}-\mathrm{CH}_{2} \mathrm{D}\right) .{ }^{13} \mathrm{C}-\mathrm{NMR}$ for compound 24 and $24-d(151 \mathrm{MHz}): \delta$, ppm: 198.1 $\left(\mathrm{C} 4^{\prime}-\mathrm{CO}-\mathrm{CH}_{3}\right), 156.7\left(\mathrm{C} 2^{\prime}\right.$ and $\left.\mathrm{C} 6^{\prime}\right), 155.0\left(\mathrm{C} 2\right.$ and $\left.\mathrm{C} 2^{\prime \prime}\right), 150.0\left(\mathrm{C} 6\right.$ and $\left.\mathrm{C}^{\prime \prime}{ }^{\prime \prime}\right), 138.0\left(\mathrm{C} 4\right.$ and $\left.\mathrm{C}^{\prime \prime}{ }^{\prime \prime}\right), 125.5$ $\left(\mathrm{C} 5\right.$ and $\left.\mathrm{C}^{\prime \prime}\right), 121.5\left(\mathrm{C} 3\right.$ and $\left.\mathrm{C}^{\prime \prime}{ }^{\prime \prime}\right), 118.2\left(\mathrm{C}^{\prime}\right.$ and $\left.\mathrm{C}^{\prime}\right), 27.7\left(\mathrm{CH}_{3}-\mathrm{CO}-\mathrm{C}^{\prime}\right) . \mathrm{D}=(2.6 \pm 0.1) \times 10^{-10} \mathrm{~m}^{2} / \mathrm{s}$. ${ }^{1} \mathrm{H}-\mathrm{NMR}$ for compound 25 (10\% with respect to the terpyridine fragment) $(600 \mathrm{MHz}): \delta, \mathrm{ppm}: 8.73$ $\left(2 \mathrm{H}, \mathrm{H} 6\right.$ and $\left.\mathrm{H}^{\prime \prime}\right), 8.62\left(2 \mathrm{H}, \mathrm{H} 3\right.$ and $\left.\mathrm{H}^{\prime \prime}{ }^{\prime \prime}\right), 8.45\left(2 \mathrm{H}, \mathrm{H}^{\prime}\right.$ and $\left.\mathrm{H} 5^{\prime}\right), 8.00\left(2 \mathrm{H}, \mathrm{H} 4\right.$ and $\left.\mathrm{H} 4^{\prime \prime}\right), 7.49(2 \mathrm{H}$, $\mathrm{H} 5$ and $\left.\mathrm{H}^{\prime \prime}{ }^{\prime \prime}\right), 4.94\left[1 \mathrm{H}, \mathrm{C} 4^{\prime}-\mathrm{CH}(-\mathrm{OH})-\mathrm{CH}_{3}\right], 1.42\left[3 \mathrm{H}, \mathrm{CH}_{3}-\mathrm{CH}(-\mathrm{OH})-\mathrm{C}^{\prime}\right] .{ }^{13} \mathrm{C}-\mathrm{NMR}$ for compound 25

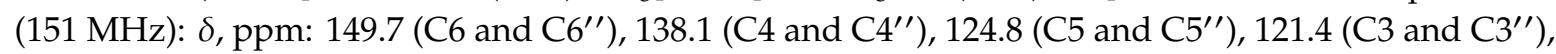
$118.2\left(\mathrm{C}^{\prime}\right.$ and $\left.\mathrm{C}^{\prime}\right), 67.8\left[\mathrm{C}^{\prime}-\mathrm{CH}(-\mathrm{OH})-\mathrm{CH}_{3}\right] . \mathrm{D}=(2.1 \pm 0.1) \times 10^{-10} \mathrm{~m}^{2} / \mathrm{s} .{ }^{1} \mathrm{H}-\mathrm{NMR}$ for unreacted 8F ( $8 \%$ with respect to the terpyridine fragment) (600 MHz): $\delta, \mathrm{ppm}: 8.73\left(2 \mathrm{H}, \mathrm{H} 6\right.$ and $\left.\mathrm{H}^{\prime \prime}\right), 8.62$ $\left(2 \mathrm{H}, \mathrm{H} 3\right.$ and $\left.\mathrm{H}^{\prime \prime}{ }^{\prime}\right), 8.42\left(2 \mathrm{H}, \mathrm{H}^{\prime}\right.$ and $\left.\mathrm{H}^{\prime}\right), 8.00\left(2 \mathrm{H}, \mathrm{H} 4\right.$ and $\left.\mathrm{H} 4^{\prime \prime}\right), 7.49\left(2 \mathrm{H}, \mathrm{H} 5\right.$ and $\left.\mathrm{H} 5^{\prime \prime}\right), 4.99$ [1H, $\left.\mathrm{C}^{\prime}-\mathrm{CH}(-\mathrm{OH})-\mathrm{CH}_{3}\right], 1.52\left[3 \mathrm{H}, \mathrm{CH}_{3}-\mathrm{CH}(-\mathrm{OH})-\mathrm{C}^{\prime}\right) .{ }^{13} \mathrm{C}-\mathrm{NMR}$ for unreacted $8 \mathrm{~F}(151 \mathrm{MHz}): \delta$, ppm: 149.7 ( $\mathrm{C} 6$ and $\left.\mathrm{C} 6^{\prime \prime}\right), 138.1$ ( $\mathrm{C} 4$ and $\left.\mathrm{C} 4^{\prime \prime}\right), 124.8$ (C5 and $\left.\mathrm{C} 5^{\prime \prime}\right), 121.4$ (C3 and $\left.\mathrm{C} 3^{\prime \prime}\right), 119.1$ (C3' and $\left.\mathrm{C} 5^{\prime}\right)$. $\mathrm{D}=(2.1 \pm 0.1) \times 10^{-10} \mathrm{~m}^{2} / \mathrm{s}$. For comparison, $\mathrm{D}$ [low spin Fe(III)-heme] $=(1.4 \pm 0.1) \times 10^{-10} \mathrm{~m}^{2} / \mathrm{s}$.

LC-MS: $t_{\mathrm{R}}[8 \mathrm{~F}]=8.0 \pm 0.1 \mathrm{~min}, \mathrm{~m} / \mathrm{z}=432.9\left(\mathrm{M}+\mathrm{H}^{+}\right) ; \mathrm{t}_{\mathrm{R}}[23]=6.7 \pm 0.1 \mathrm{~min}, \mathrm{~m} / \mathrm{z}=276.1\left(\mathrm{M}+\mathrm{H}^{+}\right)$; $t_{R}\left[\right.$ heme] $=10.5 \mathrm{~min}, \mathrm{~m} / \mathrm{z}=616.3\left(\mathrm{M}^{+}\right), 693.7\left(\mathrm{M}^{+}+\mathrm{DMSO}\right)$. 
Supplementary Materials: The following are available online. All structures of alkoxyamines whose biological evaluation is reported in Table S1: Antiplasmodial activities of alkoxyamines against chloroquine resistant FcB1-Columbia strain, and antischistosomal activities on adult $S$. mansoni are reported. Preparation and characterization of 18, $(R S / S R)-\mathbf{2 F},(R S / S R)-4 \mathrm{~F},(R S / S R)-6 \mathrm{~F},(R R / S S)-\mathbf{2 F},(R R / S S)-4 \mathrm{~F},(R R / S S)-6 \mathrm{~F},(R / S)-8 \mathrm{~F},(R S / S R)-2 \mathrm{G}$ $(R R / S S)-2 \mathrm{G},(R S / S R)-6 \mathrm{G},(R R / S S)-6 \mathrm{G}$, and $\mathrm{XRD}$ data of $(R R / S S)-6 \mathrm{~F}$ and $(R R / S S)-6 \mathrm{G}$ as well as ${ }^{1} \mathrm{H}-\mathrm{NMR}$ spectrum $(R S / S R)-2 \mathbf{F H}^{+}$and $(R R / S S)-\mathbf{2} \mathbf{F H}^{+}$in $t$-BuPh, are reported, see supplementary materials.

Author Contributions: Conceptualization, J.B., A.R., F.B.-V. and G.A.; Funding acquisition, J.B., A.R., F.B.-V. and G.A.; Investigation, T.R., T.H.T., C.E., L.P., M.N., A.H., J.-L.S., C.B., J.-P.J., J.P. and J.H.; Methodology, L.P., M.N., J.-M.A., A.R. and F.B.-V.; Resources, S.R.A.M.; Supervision, L.P., J.-M.A., J.B., A.R., F.B.-V. and G.A.; Validation, M.N., C.B., J.P., S.R.A.M., A.R. and F.B.-V.; Writing-original draft, J.-M.A., A.R. and F.B.-V.; Writing-review \& editing, T.R., C.E., L.P., M.N., J.P., S.R.A.M., J.B. and G.A. All authors have read and agreed to the published version of the manuscript.

Funding: This research was funded by ANR RADICAL (ANR-17-CE18-0017) for the financial support. JH was funded by the ANR for the PhD grant. AH was funded by the ANR for financial support. THT was funded by the Vietnamese Ministry of Education and Training for the PhD grant (Project 911). TR was funded by University Paul Sabatier, Toulouse, F. for his PhD grant. CE was funded by Campus France for his PhD grant.

Acknowledgments: The authors are grateful to Aix-Marseille Université, Université de Perpignan, Centre National de la Recherche Scientifique (CNRS) and Institut National de la Santé et de la Recherche Médicale (Inserm) for their support.

Conflicts of Interest: The authors declare no conflict of interest. The funders had no role in the design of the study; in the collection, analyses, or interpretation of data; in the writing of the manuscript, or in the decision to publish the results.

\section{References}

1. World Health Organization. World Malaria Report 2019; World Health Organization: Geneva, Switzerland, 2019; p. 185.

2. World Health Organization. Artemisinin and Artemisinin-Based Combination Therapy Resistance: Status Report; 2016. Available online: https://apps.who.int/iris/bitstream/handle/10665/250294/WHO-HTM-GMP2016.11-eng.pdf?sequence $=1 \&$ isAllowed $=y$ (accessed on 13 August 2020).

3. Duru, V.; Khim, N.; Leang, R.; Kim, S.; Domergue, A.; Kloeung, N.; Ke, S.; Chy, S.; Eam, R.; Khean, C.; et al. Plasmodium falciparum dihydroartemisinin-piperaquine failures in Cambodia are associated with mutant K13 parasites presenting high survival rates in novel piperaquine in vitro assays: Retrospective and prospective investigations. BMC Med. 2015, 13, 305. [CrossRef]

4. Witkowski, B.; Duru, V.; Khim, N.; Ross, L.S.; Saintpierre, B.; Beghain, J.; Chy, S.; Kim, S.; Ke, S.; Kloeung, N.; et al. A surrogate marker of piperaquine-resistant Plasmodium falciparum malaria: A phenotype-genotype association study. Lancet Infect. Dis. 2017, 17, 174-183. [CrossRef]

5. Ménard, S.; Ben Haddou, T.; Ramadani, A.P.; Ariey, F.; Iriart, X.; Beghain, J.; Bouchier, C.; Witkowski, B.; Berry, A.; Mercereau-Puijalon, O.; et al. Induction of multidrug tolerance in Plasmodium falciparum by extended artemisinin pressure. Emerg. Infect. Dis. 2015, 21, 1733-1741. [CrossRef]

6. Boissier, J.; Portela, J.; Pradines, V.; Coslédan, F.; Robert, A.; Meunier, B. Activity of trioxaquine PA1259 in mice infected by Schistosoma mansoni. C. R. Chimie 2012, 15, 75-78. [CrossRef]

7. Portela, J.; Boissier, J.; Gourbal, B.; Pradines, V.; Collière, V.; Coslédan, F.; Meunier, B.; Robert, A. Antischistosomal activity of trioxaquines: In vivo efficacy and mechanism of action on Schistosoma mansoni. PLoS Negl. Trop. Dis. 2012, 6, e1474. [CrossRef]

8. Robert, A.; Meunier, B. Characterization of the first covalent adduct between artemisinin and a heme model. J. Am. Chem. Soc. 1997, 119, 5968-5969. [CrossRef]

9. Robert, A.; Cazelles, J.; Meunier, B. Characterization of the alkylation product of heme by the antimalarial drug artemisinin. Angew. Chem. Int. Ed. 2001, 40, 1954-1957. [CrossRef]

10. Meunier, B.; Robert, A. Heme as triger and target for trioxane containing antimalarial drugs. Acc. Chem. Res. 2010, 43, 1444-1451. [CrossRef]

11. Cazelles, J.; Robert, A.; Meunier, B. Alkylating capacity and reaction products of antimalarial trioxanes after activation by a heme model. J. Org. Chem. 2002, 67, 609-619. [CrossRef]

12. Dechy-Cabaret, O.; Benoit-Vical, F.; Loup, C.; Robert, A.; Gornitzka, H.; Bonhoure, A.; Vial, H.; Magnaval, J.F.; Séguéla, J.P.; Meunier, B. Synthesis and antimalarial activity of trioxaquine derivatives. Chem. Eur. J. 2004, 10, 1625-1636. [CrossRef] 
13. Bousejra-El Garah, F.; Claparols, C.; Benoit-Vical, F.; Meunier, B.; Robert, A. The antimalarial trioxaquine DU1301 alkylates heme in malaria-infected mice. Antimicrob. Agents Chemother. 2008, 52, 2966-2969. [CrossRef] [PubMed]

14. Robert, A.; Benoit-Vical, F.; Claparols, C.; Meunier, B. The antimalarial drug artemisinin alkylates heme in infected mice. Proc. Natl. Acad. Sci. USA 2005, 102, 13676-13680. [CrossRef] [PubMed]

15. Robert, A.; Claparols, C.; Witkowski, B.; Benoit-Vical, F. Correlation between plasmodium yoelii nigeriensis susceptibility to artemisinin and alkylation of heme by the drug. Antimicrob. Agents Chemother. 2013, 57, 3998-4000. [CrossRef]

16. Pradines, V.; Portela, J.; Boissier, J.; Coslédan, F.; Meunier, B.; Robert, A. Trioxaquine PA1259 alkylates heme in the blood-feeding parasite Schistosoma mansoni. Antimicrob. Agents Chemother. 2011, 55, 2403-2405. [CrossRef]

17. Audran, G.; Brémond, P.; Marque, S.R.A.; Obame, G. Chemically triggered C-ON bond homolysis of alkoxyamines. 5. Cybotactic Effect. J. Org. Chem. 2012, 77, 9634-9640. [CrossRef]

18. Audran, G.; Brémond, P.; Marque, S.R.A.; Obame, G. Chemically triggered C-ON bond homolysis of alkoxyamines. Part 4. Solvent Effect. Polym. Chem. 2012, 3, 2901-2908. [CrossRef]

19. Audran, G.; Brémond, P.; Joly, J.P.; Marque, S.R.A.; Yamasaki, T. C-ON Bond homolysis of alkoxyamines. Part 12: Effect of the para-substituent in the 1-Phenylethyl fragment. Org. Biomol. Chem. 2016, 14, 3574-3583. [CrossRef]

20. Audran, G.; Brémond, P.; Marque, S.R.A.; Yamasaki, T. C-ON bond homolysis of alkoxyamines. Part 11: Activation of the nitroxyl fragment. J. Org. Chem. 2016, 81, 1981-1988. [CrossRef]

21. Audran, G.; Bikanga, R.; Brémond, P.; Joly, J.P.; Marque, S.R.A.; Nkolo, P. C-ON bond homolysis of alkoxyamines: Activation of the nitroxyl fragment. Normal, leveled, and enhanced steric effects in alkoxyamines carrying $\alpha, \beta$-phosphorylated nitroxyl fragment. J. Org. Chem. 2017, 82, 5702-5709. [CrossRef]

22. Nkolo, P.; Audran, G.; Bikanga, R.; Brémond, P.; Marque, S.R.A.; Roubaud, V. C-ON Bond homolysis of alkoxyamine: When too high polarity is detrimental. Org. Biomol. Chem. 2017, 15, 6167-6176. [CrossRef]

23. Audran, G.; Bikanga, R.; Brémond, P.; Edeleva, M.; Marque, S.R.A.; Nkolo, P.; Roubaud, V. How intramolecular hydrogen bonding (IHB) controls the $\mathrm{C}-\mathrm{ON}$ bond homolysis in alkoxyamines. Org. Biomol. Chem. 2017, 15, 8425-8439. [CrossRef]

24. Yamasaki, T.; Buric, D.; Chacon, C.; Audran, G.; Braguer, D.; Marque, S.; Carré, M.; Brémond, P. Chemical modifications of imidazole-containing alkoxyamines increase $\mathrm{C}-\mathrm{ON}$ bond homolysis rate: Effects on their cytotoxic properties in glioblastoma cells. Bioorg. Med. Chem. 2019, 27, 1942-1951. [CrossRef]

25. Nkolo, P. Synthesis and Physico-Chemical Study of New Activatable Alkoxyamines to Fight Malaria. Ph.D. Thesis, University of Aix-Marseille, Marseille, France, 2017.

26. To, H.T. Development of New Alkoxyamines Releasing Free Radicals against the Two Major Parasitic Diseases Malaria and Schistosomiasis. Ph.D. Thesis, University of Aix-Marseille, Marseille, France, 2019.

27. To, H.T.; Audran, G.; Marque, S.R.A.; N'kolo, P.; Edeleva, M.; Cherkasov, S.; Bagryanskaya, E.; Bikanga, R.; Joly, J.-P. Synthesis of alkoxyamines based on bipyridine and acridine fragments. Org Biomol. Chem. 2021, in preparation.

28. Potts, K.T.; Konwar, D. Synthesis of $4^{\prime}$-Vinyl-2,2':6' $2^{\prime \prime}$-terpyridine. J. Org. Chem. 1991, 56, 4815-4816. [CrossRef]

29. Bertin, D.; Gigmes, D.; Marque, S.R.A. Trialkylhydroxylamines (alkoxyamines) in radical chemistry: Preparation, stability and applications. Recent Res. Devel. Org. Chem. 2006, 10, 63-121.

30. Crystallographic Data for the Structure of $(R R / S S)-2 \mathrm{G}$ and $(R R / S S)-6$ F Were Deposited with the Cambridge Crystallographic Data Centre (CCDC) as Supplementary Publication for the Present Article, With No. CCDC 1938691 and CCDC 1938657, Respectively. Copies of the Data Can Be Obtained Free of Charge from the CCDC (12 Union Road, Cambridge CB2 1EZ, UK). Available online: http://www.ccdc.cam.ac.uk (accessed on 10 August 2020).

31. Trost, B.M.; Caldwell, G.; Murayama, D.; Heissler, D. Sulfur-substituted dienes and the silylene protecting group in synthesis. Deoxypillaromycinone. J. Org. Chem. 1983, 48, 3252-3265. [CrossRef]

32. Dess, D.B.; Martin, J.C. A useful 12-I-5 triacetoxyperiodinane (the Dess-Martin periodinane) for the selective oxidation of primary or secondary alcohols and a variety of related 12-I-5 species. J. Am. Chem. Soc. 1991, 113, 7277-7287. [CrossRef] 
33. Bal, B.S.; Childers, W.E.J.; Pinnick, H.W. Oxidation of $\alpha, \beta$-unsaturated aldehydes. Tetrahedron 1981, 37, 2091-2096. [CrossRef]

34. Sun, Q.; Mao, R.; Wang, D.; Hu, C.; Zheng, Y.; Sun, D. The cytotoxicity study of praziquantel enantiomers. Drug Des. Dev. Ther. 2016, 10, 2061-2068. [CrossRef]

35. Witkowski, B.; Lelièvre, J.; López Barragán, M.J.; Laurent, V.; Su, X.; Berry, A.; Benoit-Vical, F. Increased tolerance to artemisinin in Plasmodium falciparum is mediated by a quiescence mechanism. Antimicrob. Agents Chemother. 2010, 54, 1872-1877. [CrossRef]

36. Krȩżel, A.; Bal, W. A formula for correlating $\mathrm{pK}_{\mathrm{a}}$ values determined in $\mathrm{D}_{2} \mathrm{O}$ and $\mathrm{H}_{2} \mathrm{O}$. J. Inorg. Biochem. 2004, 98, 161-166. [CrossRef] [PubMed]

37. Fuchs, J.; Groth, N.; Herrling, T.; Zimmer, G. Electron paramagnetic resonance studies on nitroxide radical 2,2,5,5-tetramethyl-4-piperidin-1-oxyl (TEMPO) redox reactions in human skin. Free Radic. Biol. Med. 1997, 22, 967-976. [CrossRef]

38. Ingold, K.U. Peroxy radicals. Acc. Chem. Res. 1969, 2, 1-9. [CrossRef]

39. Soule, B.P.; Hyodo, F.; Matsumoto, K.I.; Simone, N.L.; Cook, J.A.; Krishna, M.C.; Mitchell, J.B. The chemistry and biology of nitroxide compounds. Free Radic. Biol. Med. 2007, 42, 1632-1650. [CrossRef] [PubMed]

40. Lewandowski, M.; Gwozdzinski, K. Nitroxides as antioxidants and anticancer drugs. Int. J. Mol. Sci. 2017, 18, 2490. [CrossRef]

41. Wilcox, C.S.; Pearlman, A. Chemistry and antihypertensive effects of tempol and other nitroxides. Pharm. Rev. 2008, 60, 418-469. [CrossRef]

42. Ariey, F.; Witkowski, B.; Amaratunga, C.; Beghain, J.; Langlois, A.C.; Khim, N.; Kim, S.; Duru, V.; Bouchier, C.; Ma, L.; et al. A molecular marker of artemisinin-resistant Plasmodium falciparum malaria. Nature 2014, 505, 50-55. [CrossRef]

43. Trager, W.; Jensen, J.B. Human malaria parasites in continuous culture. Science 1976, 19, 673-675. [CrossRef]

44. Smilkstein, M.; Sriwilaijaroen, N.; Kelly, J.X.; Wilairat, P.; Riscoe, M. Simple and inexpensive fluorescence-based technique for high-throughput antimalarial drug screening. Antimicrob. Agents Chemother. 2004, 48, 1803-1806. [CrossRef]

45. Lambros, C.; Vanderberg, J.P. Synchronization of Plasmodium falciparum erythrocytic stages in culture. J. Parasitol. 1979, 65, 418-420. [CrossRef]

46. Dumont, M.; Moné, H.; Mouahid, G.; Idris, M.A.; Shaban, M.; Boissier, J. Influence of pattern of exposure, parasite genetic diversity and sex on the degree of protection against reinfection with Schistosoma mansoni. Parasitol. Res. 2007, 101, 247-252. [CrossRef] [PubMed]

47. Ammerman, N.C.; Beier-Sexton, M.; Azad, A.F. Growth and maintenance of Vero cell lines. Curr. Protoc. Microbiol. 2008, 11, A.4E.1-A.4E.7. [CrossRef] [PubMed]

48. Mosmann, T. Rapid colorimetric assay for cellular growth and survival: Application to proliferation and cytotoxicity assays. J. Immunol. Methods 1983, 65, 55-63. [CrossRef]

49. Gaussian 09; Revision D.01; Software for Quantum Chemical Calculations; Gaussian, Inc.: Wallingford, CT, USA, 2013.

50. Tomasi, J.; Mennucci, B.; Cammi, R. Quantum mechanical continuum solvation models. Chem. Rev. 2005, 105, 2999-3093. [CrossRef]

Sample Availability: Samples of the compounds are not available from the authors. 